


\section{Price 15 Conts. \\ HUMBOLDT LIBRARY. [No, 43.}

Wo Supplied to the Irade, ReturNABLE, by the Nerws Companies.

\section{DARWIN}

BY PROF. HUXLEY AND OTHERS;

\section{AND}

\section{HUMBOLDT.}

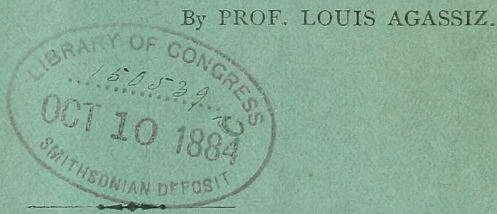

PREVIOUS ISSUES OF THE LIBRARY :

No. 40, The Scientific Evidence of Organic Evolution. By George J. Romanes, F.R.S.

No. 41, Current Discussions in Science. By W. M. Whlliams, F.R.A.S.

No. 42, The History of the Science of Politics. BY Frederick Pollock.

See the Catalogue on last page of cover.

Covers for the LiERARY, to hold firmly any number of copies from one to twelve,

Price, 60 Cents ; to Subscribers, 35 Cents.

\section{J. FITZGERALD, PUBLISHER,} 30 LAFAYETTE PLACE, NEW YORK. 


\section{TWO BOUND VOLUMES}

OF

\section{THE HUMBOLDT LIBRARY INOW IREJADT.}

Vol. I, Containing the first $2 \iota_{r}$ Numbers, Quarto size, $75^{\circ}$ pages. Price \$4.00. (Postage prepaid.)

Vol. II Contains the following Works:

The Origin of Nations.

By Pruf. Geo. Rawlinson, Oxford Univ.

The Evolutionist at 1 arge.

By Grant Allen.

The History of Landholding in Fngland.

By Joseph FISHeR, F.R.H.S.

Fashion in Deformity, as illustrated in the customs of Barbarous and Civilized Races. (Numerous illustrations).

By William Henry Fluwer, F.R S.

Facts and Fictions of Zoology, (numerous itlustrations).

By Andrew Wilson, Ph.D.

\section{Sold ONLY by the Publishers.}

Prife, - - \$1.50. Postage additional, - - 25 Cents.

\section{TWO VALUABLE WORKS ON MUSIC.}

$$
\begin{aligned}
& \text { By ISAAC L. RICE, LL.B., } \\
& \text { Lecturer in Columbia College, New York. }
\end{aligned}
$$

1. What is Music? Price, cloth, 50 cents; paper, 25 cents.

Evrening Post, N. Y.- "Cannot fail to fascinate those who are fond of music, or of contemplating the laws which in the works of nature are seen in full operation."

II. How the Geometrical Lines Have Their Counterparts in Music. Price; paper, 12 cents.

Evening Mail, N. Y.-" Manifests subtle thought and a keen perception of the deep foundation on which music rests."

As these works are not for sale by the book trade, orders should be sent direct to

\section{J. FITZGERALD,}

30 LAFAYETTE PLACE, NEW YORK. 
HUMBOLDT

oF

\section{POPULAR SCIENCE LITERATURE.}

No. 43.]

NEW YORK: J. FITZGERALD.

[Fifteen Cents.

April, $188_{3}$.

Entered at the New York Post-Office as Second-Class Matter.

$\$ 1.50$ per Year (12 Numbers).
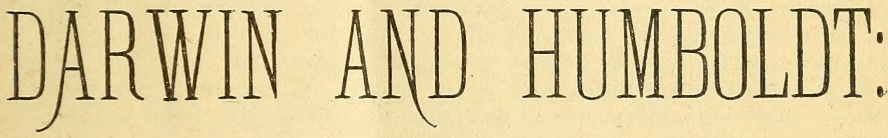

THEIR LIVES AND WORK.

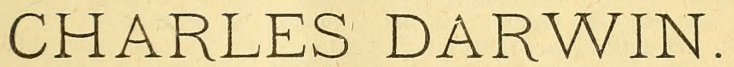

\section{INTRODUCTORY NOTICE.}

BY PROF. T. H. HUXLEY, F.R.S.

Very few, even among those who have taken the keenest interest in the progress of the revolution in natural knowledge set afoot by the publication of the Origin of Species, and who have watched, not without astonishment, the rapid and complete change which has been effected both inside and outside the boundaries of the scientific world in the attitude of men's minds toward the doctrines which are expounded in that great work, can have been prepared for the extraordinary manifestation of affectionate regard for the man, and of profound reverence for the philosopher, which followed the announcement of the death of Mr. DarwiN.
Not only in these islands, where so many have felt the fascination of personal contact with an intellect which had no superior, and with a character which was even nobler than the intellect; but, in all parts of the civilized world, it would seem that those whose business it is to feel the pulse of nations and to know what interests the masses of mankind, were well aware that thousands of their readers would think the world the poorer for DARwis's death, and would dwell with eager interest upon every incident of his history. In France, in Germany, in Austro-Hungary, in Italy, in the United States, writers of all shades of opinion, for once unanimous, have paid a willing tribute to the worth of our great countryman, ignored in life by the official representatives of the kingdom, but laid in 
death among his peers in Westminster Abbey by the will of the intelligence of the nation.

It is not for us to allude to the sacred sorrows of the bereaved home at Down; but it is no. secret that, outside that domestic group, there are many to whom Mr. Darwin's death is a wholly irreparable loss. And this not merely because of his wonderfully genial, simple, and generous nature; his cheerful and animated conversation, and the infinite variety and accuracy of his information; but because the more one knew of him, the more he seemed the incorporated ideal of a man of science. Acute as were his reasoning powers, vast as was his knowledge, marvelous as was his tenacious industry, under physical difficulties which would have converted nine men out of ten into aimless invalids; it was not these qualities, great as they were, which impressed those who were admitted to his intimacy with involuntary veneration, but a certain intense and almost passionate honesty by which all his thoughts and actions were irradiated, as by a central fire.

It was this rarest and greatest of endowments which kept his vivid imagination and great speculative powers within due bounds; which compelled him to undertake the prodigious labors of original investigation and of reading, upon which his published works are based; which made him accept criticisms and suggestions from any body and every body, not only without impatience, but with expressions of gratitude sometimes almost comically in excess of their value; which led him to allow neither himself nor others to be deceived by phrases, and to spare neither time nor pains in order to obtain clear and distinct ideas upon every topic with which he occupied himself.

One could not converse with DARwIN without being reminded of SoCrates. There was the same desire to find some one wiser than himself; the same belief in the sovereignty of reason; the same ready humor; the same sympathetic interest in all the ways and works of men. But instead of turning away from the problems of nature as hopelessly insoluble, our modern Philosopher devoted his whole life to attacking them in the spirit of Heraclitus and of DeMOCRITUs, with results which are as the substance of which their speculation were anticipatory shadows.

The due appreciation or even enumeration of these results is neither practicable nor desirable at this mo ment. There is a time for all things - a time for glorying in our everextending conquests over the realm of nature, and a time for mourning over the heroes who have led us to victory.

None have fought better, and none have been more fortunate, than Charles Darwin. He found a great truth trodden under foot, reviled by bigots, and ridiculed by all the world; he lived long enough to see it, chiefly by his own efforts, irrefragably established in science, inseparably incorporated with the common thoughts of men, and only hated and feared by those who would revile, but dare not. What shall a man more desire than this? Once more the image of Socrates rises unbidden, and the noble peroration of the Apology rings in our ears as if it were Charles Darwin's farewell:

"The hour of departure has arrived, and we go our ways-I to die, and you to live. Which is the better, God only knows."

\section{CHARACTER AND LIFE.}

BY G. J. ROMANES, F.R.S.

The object of this notice is to give a brief account of the life, and a pro. portionately still more brief account of the work of Mr. Darwin. But while we recognize in him perhaps the greatest genus and the most fertile thinker, certainly the most important generalizer and one of the few most 
successful observers in the whole histo ry of biological science, we feel that no less great, or even greater than the wonderful intellect was the character of the man. Therefore it is in his case particularly and pre-eminently true that the first duty of biographers will be to render some idea, not of what he did, but of what he was. And this, unfortunately, is just the point where all his biographers must necessarily fail. For while to those favored few who were on terms of intimate friendship with him, any language by which it is sought to portray his character must seem inadequate, to every one else the same language must appear the result of enthusiastic admiration, finding vent in extravagant panegyric. Whatever is great and whatever is beautiful in human nature found in him so luxuriant a development, that no place or chance was left for any other growth, and in the result we beheld a magnificence which, unless actually realized, we should scarcely have been able to imagine. Any attempt, therefore, to describe such a character must be much like an attempt to describe a splendid piece of natural scenery or a marvelous work of art; the thing must itself have been seen, if any description of it is to be understood.

But without attempting to describe Mr. DaRwiN's character, if we were asked to indicate the features which stood out with most marked prominence, we should first mention those which, from being conspicuous in his writings, are already more or less known to all the world. Thus, the absorbing desire to seek out truth for truth's sake, combined with a characteristic disregard of self, led not only to the caution, patience, and candor of his own work-which are proverbial-and to the generous satisfaction which he felt on finding any of his thoughts or results independently attained by the work of others; but also to a keen and vivid freshness of interest in every detail of a new research, such as we have sometimes seen approached by much younger men when the research happens to have been their own. And indeed what we may call this fervid youthfulness of feeling extended through all Mr. DARwIN's mind, giving, in combination with his immense knowledge and massive sagacity, an indescribable charm to his manner and conversation. Animated and fond of humor, his wit was- of a singularly fascinating kind, not only because it was always brilliant and amusing, but still more because it was always hearty and good-natured. Indeed, he was so exquisitely refined in his own feelings, and so almost painfully sensitive to any display of questionable taste in others, that he could not help showing in his humor, as in the warp and woof of his whole nature, that in him the man of science and the philosopher were subordinate to the gentleman. His courteous consideration of others, also, which went far beyond anything that the ordinary usages of society require, was similarly prompted by his mere spontaneous instinct of benevolence.

For who can always act? but he,

To whom a thousand memories call

Not being less but more than all

The gentleness he seemed to be,

Best seem'd the thing he was, and join'd

Each office of the social hour

To noble manners, as the flower

And native growth of noble mind ;

Nor eyer narrowness or spite,

Or villain fancy fleeting by,

Drew in the expression of an eye,

Where God and nature met in light.

And this leads us to speak of his kindness, which, whether we look to its depth or to its width, must certainly be regarded as perhaps the most remarkable feature of his remarkable disposition. The genuine delight that he took in helping every one in their work-often at the cost of much personal trouble to himself-in throwing out numberless suggestions for others to profit by, and in kindling the enthusiasm of the humblest tyro in science; this was the outcome of a great and generous heart, quite as 
much as it was due to a desire for the advancement of science. Nothing seemed to give him a keener joy than being able to write to any of his friends a warm and glowing congratulation upon their gaining some success; and the exuberance of his feelings on such occassions generally led him to conceive a much higher estimate of the importance of the results attained than he would have held had the success been achieved by himself. For the modesty with which he regarded his own work was no less remarkable than his readiness enthusiastically to admire the work of others; so that, to any one who did not know him well, this extreme modesty, from its very completeness and unconsciousness, might almost have appeared the result of affectation. At least, speaking for ourselves, when we first met him, and happened to see him conversing with a greatly younger man, quite unknown either in science or literature, we thought it must have been impossible that Mr. DARwINthen the law giver to the world of biology-could with honest sincerity be submitting, in the way he did, his matured thought to the judgment of such a youth. But afterward we came fully to learn that no one was so unconscious of Mr. DARwin's worth as Mr. DARwIN himself, and that it was a fixed habit of his mind to seek for opinions as well as facts from every available quarter. It must be added, however, that his tendency to go beyond the Scriptural injunction in the matter of selfapproval, and to think of others more highly than he ought to think, never clouded his final judgment upon the value of their opinions; but spontaneously following another of these injunctions, while proving all things, he held fast only to that which was good. "In malice be ye children, but in understanding be ye men."

On the whole, then, we should say that Mr. DARwIN's character was chiefly marked by a certain grand and cheerful simplicity, strangely and beautifully united with a deep and thoughtful wisdom, which, together with his illimitable kindness to others and complete forgetfulness of himself, made a combination as lovable as it was venerable. It is, therefore, not to be wondered at that no man ever passed away leaving behind him a greater void of enmity, or a depth of adoring friendship more profound.

But, as we have said, it is impossible to convey in words any adequate conception of a character which in beauty as in grandeur can only, with all sobriety, be called sublime. If the generations are ever to learn, with any approach to accuracy, what Mr. DARwin was, his biographers may best teach them by allowing this most extraordinary man to speak for himself through the medium of his correspondence, as well as through that of his books; and therefore, as a small foretaste of the complete biography which will some day appear, we shall quote a letter in which he describes the character of his great friend and teacher, the late Prof. Henslow, of Cambridge. We choose this letter to quote from on account of the singular manner in which the writer, while describing the character of another, is unconsciously giving a most accurate description of his own. It is of importance also that in any biographical history of Mr. DARwin, Professor Henslow's character should be duly considered, seeing that he exerted so great an influence upon the expanding powers of Mr. Darwin's mind. We quote the letter from the Rev. L. Jenrns's Memoir of the late Prof. Henslow.

"I went to Cambridge early in the year 1828 , and soon became acquainted, through some of my brother entomulogists, with Prof. Henslow, for all who cared for any branch of natural history were equally encouraged by him. Nothing could be more simple, cordial, and unpretending than the encouragement which he afforded to all young naturalists. I soon became intimate with him, for he had a remarkable power of mak- 
ing the young feel completely at ease with him, though we were all awestruck with the amount of his knowledge. Before I saw him, I heard one young man sum up his attainments by simply saying that he knew everything. When I reflect how immediately we felt at perfect ease with a man older, and in every way so immensely our superior, I think it was as much owing to the transparent sincerity of his character as to his kindness of heart, and perhaps even stiil more to a highly remarkable absence in him of all self-consciousness. We perceived at once that he never thought of his own varied knowledge or clear intellect, but solely on the subject in hand. Another charm, which must have struck every one, was that his manner to a distinguished person and to the youngest student was exactly the same: to all, the same winning courtesy. He would receive with interest the most trifling observation in any branch of natural history, and however absurd a blunder one might make, he pointed it out so clearly and kindly that one left him in no way disheartened, but only determined to be more accurate the next time. So that no man could be better formed to win the entire confidence of the young and to encourage them in their pursuits...

"During the years when I associated so much with Prof. Henseow, I never once saw his temper even ruffled. He never took an ill natured view of any one's character, though very far from blind to the foibles of others. It always struck me that his mind could not be well touched by any paltry feeling of envy, vanity, or jealousy. With all this equability of temper, and remarkable benevolence, there was no insipidity of character. A man must have been blind not to have perceived that beneath this placid exterior there was a vigorous and determined will. When principle came into play, no power on earth could have turned him an hair's breadth. . . .

"In intellect, as far as I could judge, accurate powers of observation, sound sense, and cautious judgment seemed to predominate. Nothing seemed to give him so much enjoy. ment as drawing conclusions from minute observations. But his admirable memoir on the geology of Anglesea shows his capacity for extended observations and broad views. Reflecting over his character with gratitude and reverence, his moral attributes rise, as they should do in the highest characters, in pre-eminence, over his intellect."

Charles Robert Darwin was born at Shrewsbury on February 12, 1809. His father was Dr. R. W. Darwiv, F.R.S., a physician of eminence, who, as his son used frequently to remark, had a wonderful power of diagnosing diseases, both bodily and mental, by the aid of the fewest possible questions; and his quickness of perception was such that he could even divine, in a remarkable manner, what was passing through his patients' minds. That, like his son, he was benevolently inclined, may be inferred from a little anecdote which we once heard Mr. Darwis tell of him while speaking of the curious kinds of pride which are sometimes shown by the poor. For the benefit of the district in which he lived Dr. Darwin offered to dispense medicines gratis to any one who applied and was not able to pay. $\mathrm{He}$ was surprised to find that very few of the sick poor availed themselves of his offer, and guessing that the reason must have been a dislike to becoming the recipients of charity, he devised a plan to neutralize this feeling. Whenever any poor persons applied for medical aid, he told them that he would supply the medicine, but that they must pay for the bottles. This little distinction made all the difference, and ever afterward the poor used to flock to the doctor's house for relief as a matter of right.

Mr. Darwin's mother was a daughter of Josiah Wedgwood. Little is at present known concerning his early life, and it is questionable 
whether we can hope to learn much with reference to his boyhood or youth, till the time when he entered at Edinburgh. We can, therefore, only say that he went to Shrewsbury School, the head master of which was at that time Dr. Burler, afterward Bishop of Lichfield. He was sent to Edinburgh (1825) because it was intended that he should follow his father's profession, and Edinburgh was then the best medical school in the kingalom. He studied under Prof Jameson, but does not seem to have profited at all by whatever instruction he received; for not only did it fail to awaken in him any special love of natural history, but even seems to have had the contrary effect.

The prospect of being a medical practitioner proving distasteful to him, he was, after two sessions at Edinburgh, removed to Christ's College, Cambridge, with the view of his entering the Church. $\mathrm{He}$ took his B.A. in 1831, and his M.A. in 1837. There being no Natural Sciences Tripos at that time, his degree was an ordinary one. While at Cambridge he attracted the notice of the late Rev. Prof. Henslow, who had just previously exchanged the Professorship of Mineralogy for that of Botany. From the above description of this man's character and attainments, it is sufficiently evident that he was a worthy teacher of a worthy pupil; and the world owes an immense debt of gratitude to him for having been the means of enthusiastically arousing and sagaciously directing the first love and the early study of natural science in the mind of Darwin. No one can be more deeply moved by a sense of this gratitude than was Mr. DARwIN himself. His letters, written to Prof. Hensuow during his voyage round the world, overflow with feelings of affection, veneration, and obligation to his accomplished master and dearest friend - feelings which throughout his life he retained with undiminished intensity. As he used himself to say, before he knew Prof. Hensuow, the only objects of natural history for which he cared were foxes and partridges. But owing to the impulse which he derived from the field excursions of the Hensuow class, he became while at Cambridge an ardent collector, especially in the region of entomology; and we remember having heard him observe that the first time he ever saw his own name in print was in connection with the capture of an insect in the fens.

During one of the excursions Prof. Henslow told him that he had been commissioned (through Prof. PEACoCK) to offer any competent young naturalist the opportunity of accompanying Captain Fitzroy as a guest on the surveying voyage of the Beagle, and that he would strongly urge its acceptance on him. Mr. DARwin had already formed Cesire to trarel, having been stimulated thereto by reading Humbor.ut's Personal Narrative; so after a short hesitation on the part of his father, who feared that the voyage might "unsettle" him for the Church, the matter was soon decided, and in De. cember of 1838 the expedition started. During the voyage he suffered greatly from sea-sickness, which, together with the fasting and fatigue incidental to long excursions over-land, was. probably instrumental in producing the dyspepsia to which, during the: remainder of his life, he was a victim. Three years after returning from this. voyage of circumnavigation, he married, and in 1842 settled at Down, in Kent. The work which afterward emanated from that quiet and happy English home, which continued up to the day of his death, and which has been more effectual than any other in making the nineteenth century illustrious, will form the subject of our subsequent articles. 


\section{WORK IN GEOLOGY.}

BX ARCHIBALD GEIKIE, F.R.S.

No man of his time has exercised upon the science of Geology a profounder influence than CHARLES DARwis. At an early period of his life he took much interest in geological studies, and in later years, while engaged in other pursuits, he kept himself acquainted with the progress that was being made in this department of natural knowledge. His influence upon it has been twofold, arising partly from the importance and originality of some of his own contributions to the literature of the science, but chiefly from the bearing of his work on other branches of natural history.

When he began to direct his attention to geologieal inquiry the sway of the Cataclysmal school of geology was still paramount. But already the Uniformitarians were gathering strength, and, before many years were past, had ranged themselves under the banner of their great champion, Iyeli. Darwin, who always recognized his indebtedness to Lreuc's teaching, gave a powerful impulse to its general reception by the way in which he gathered from all parts of the world facts in its support. He continually sought in the phenomena of the present time the explanation of those of the past. Yet he was all the while laying the foundation on which the later or Evolutional school of geology has been built up.

DARWIN's specially geological memoirs are not numerous, nor have they been of the same epoch-making kind as his biological researches. But every one of them bears the stamp of his marvelous acuteness in observation, his sagacity in grouping scattered facts, and his unrivalled farreaching vision that commanded all their mutual bearings, as well as their place in the general economy of things. His long travels in the Beagle afforded him opportunities of making him- self acquainted with geological phenomena of the most varied kinds. With the exception of one or two minor papers written in later years, it may be said that all his direet contributions to geology arose out of the Beagle voyage. The largest and most important part of his geological work deal with the hypogene forces of nature--those that are concerned in volcanoes and earthquakes, in the elevation of mountains and continents, in the subsidence of vast areas of the sea-bottom, and in the erumpling, foliation, and cleavage of the rocks. of the earth's crust. His researches. in these subjects were mainly embodied in the Geology of the Voyage of the Beagle-a work which, in three successive parts, was published under the auspices of the Lords of the Treasury.

The order chosen by DARwIN for the subjects of these three parts. probably indicates the relative importance with which they were regarded by himself. The first was entitled The Structure and Distribution of Coral Reefs (1842). This well-known treatise, the most original of all its author's geological: memoirs, has become one of the recognized classies of geological literature. The origin of those remarkable rings of coral-rock in mid-ocean had given rise to much speculation, but no satisfactory solution of the problem had been proposed. After visiting many of them, and examining also coral-reefs that fringe islands and continents, he offered a theory which for simplicity and grandeur strikes every reader with astonishment. It is pleasant after the lapse of many years to recall the delight with which one first read the Coral Reefs, how one watched the facts being marshalled into their places, nothing being ignored or passed lightly over, and how step by step one was led up to the grand conclusion of wide oceanic. subsidence. No more admirable example of scientific method was ever given to the world, and even if he had written nothing else, this 
treatise alone would have placed $D_{A R-}$ wiv in the very front of investigators of nature.

The second part was entitled Geological Observations of the Volcanic Islands visited during the Voyage of H.M.S. Beagle, together with some Brief Notices on the Geology of Australia and the Cape of Good Hope (1844). Full of detailed observations, this work still remains the best authority on the general geological structure of most of the regions it describes. At the time it was written, the "Crater of Elevation theory," though -opposed by Constant, Prevost, Scrope, and Lyest, was generally accepted, at least on the Continent. DARWIN, however, could not receive it as a valid explanation of the facts, and though he did not adopt the views of its chief opponents, but ventured to propose a hypothesis of his own, the observations impartially made and described by him in this volume must be regarded as having contributed toward the final solution of the question.

The third and concluding part bore the title of Geological Observations on South America (1846). In this work the author embodied all the materials collected by him for the illustration of South American geology save some which had already been published elsewhere. One of the most important features of the book was the evidence which it brought forward to prove the slow, interrupted elevation of the South American Continent during a recent geological period. On the western sea-board he showed that beds of marine shells could be traced more or less continuously for a distance of upward of 2,000 miles, that the elevation had been unequal, reaching in some places at least to as much as 1,300 feet, that in one instance, at a hight of 85 feet above the sea, undoubted traces of the presence of man occurred in a raised beach, and hence that the land had there risen 85 feet since Indian man had inhabited Peru.
These proofs of recent elevation may have influenced him in the conclusinn which he drew as to the marine origin of the great elevated plains of Chili. But at that time there was a general tendency among British geologists to detect evidence of sea-action everywhere, and to ignore or minimize the action of running water and winddrift upon the land. An important chapter of the volume, devoted to a discussion of the phenomena of cleavage and foliation, is well known to every student of the literature of metamorphism.

The official records of the Beagle did not, however, include all that DARwin wrote on the geology of the voyage. Hecontributed to the Transactions of the Geological Society (vol. v. 1840) a paper on the connection of volcanic phenomena. In the same publication (vi. 1842) appears another, on the erratic boulders of South America; while a third, on the geology of the Falkland Islanōs, was published later

While dealing with the subterranean agents in geological change, he kept at the same time an ever wachful eye upon the superficial operations by which the surface of the globe is modified. He is one of the earliest writers to recognize the magnitude of the denudation to which even recent geological accumulations have been subjected. One of the most impressive lessons to be learnt from his account of Volcanic Islands is the prodigious extent to which they have been denuded. As just stated, he was disposed to attribute more of this work to the action of the sea than most geologists would now admit; but he lived himself to modify his original views, and on this subject his latest utterances are quite abreast of the time. It is interesting to note that one of his early geological papers was on the Formation of Mould (1840), and that after the lapse of forty years he returned to this subject, devoting to it the last of his volumes. In the first sketch we see the patient observation and shrewdness of inference so 
eminently characteristic of the writer, and in the finished work the same faculties enriched with the experience of a long and busy life. In bringing to light the operations of the earthworm, he called the attention of geologists to an agency, the real efficiency of which they probably do not yet appreciate. ELIE DE BEAUMONT looked upon the layer of grasscovered soil as a permanent datumline from which the denudation of exposed surfaces might be measured. But, as DARwin showed, the constant transference of soil from beneath to the surface, and the consequent exposure of the materials so transferred to be dried and blown away by wind, or to be washed to lower levels by rain, must tend slowly but certainly to lower the level even of undisturbed grass-covered land.

To another of his early papers reference may be made, from its interest in the history of British geology. BuckLAND, following in the footsteps of AgAssiz, had initiated that prodigious amount of literature which has now been devoted to the records of the Glacial period in this country, by reading to the Geological Society a paper "On Diluvio-glacial Phenomena in Snowdonia and in adjacent parts of North Wales" (1841). DARWIN, whose wanderings in South American had led him to study the problems presented by erratic blocks, took an early opportunity of visiting the Welsh district described by BuckLAND, and at once declared himself to be a believer in the former presence of glaciers in Britain. His paper (1843) in which this belief is stated and enforced by additional observations, stands almost at the top of the long list of English contributions to the history of the Ice Age.

The influence exercised upon the progress of geology by DARwin's researches in other than geological fields, is less easy to be appraised. Yet it has been far more widespread and profound than that of his direct geological work. Even as far back as the time of the voyage of the
Beagle, he had been led to reflect deeply on some of LXELL's speculations upon the influence of geological changes on the geographical distribution of animals. From that time the intimate connection between geological history and biological progress seems to have been continually present in his mind. It was not, however, until the appearance of the Origin of Species in 1859 that the full import of his reflections was perceived. His chapter on the "Imperfection of the Geological Record" startled geologists as from a profound slumber. It would be incorrect to say that he was the first to recognize the incompleteness of the record; but certainly until the appearance of that famous ehapter the general body of geologists was blissfully unconscious of the essentially fragmentary character of the geological record. DARwIN showed why this must necessarily be the ease ; how multitudes of organic types, both of the sea and of the land, must have decayed and never have been preserved in any geological deposit; how, even if entombed in such accumulations, they would in great measure be dissolved away by the subsequent percolation of water. Returning to some of his early speculations, he pointed out that massive geological deposits rich in fossils could only have been laid down during subsidence, and only where the supply of sediment was sufficient to let the sea remain , shallow, and to entomb the organic remains on its floor before they had decayed. Hence, by the very conditions of its formation, the geological record, instead of being a continuous and tolerably complete chronicle, must be intermittent and fragmentary. The sudden appearance of whole groups of allied species of fossils on certain horizons had been assumed by some eminent authorities as a fatal objection to any doctrine of the transmutation of species. But Darwin now claimed this fact as only another evidence of the enormous gaps in geological history. Reiterating again and again 
that only a small fraction of the world had been examined geologically, and that even that fraction was still but imperfectly known, he called attention to the history of geological discovery as furnishing itself a strong argument against those who reasoned as if the geological record were a full chronicle of the history of life upon the earth. There is a natural tendency to look upon the horizon upon which a fossil species first appears as marking its birth, and that on which it finally disappears as indicating its extinction. DARWIN declared this assumption to be "rash in the extreme." No palæontologist or geologist will now gainsay this assertion. And yet how continually do we still hear men talking of the stages of the geological record, as if these were sharply marked off everywhere by the first appearance and final disappearance of certain species. The boldness with which DARwIN challenged some of these long-rooted beliefs is not less conspicuous than the modesty and deference with which his own suggestions were always given. "It is notorious," he remarked, "on what excessively slight differences many palæontologists have founded their species; and they do this the more readily if the specimens come from different sub-stages of the same formation."

Starting from this conception of the nature of the geological record, DARWIN could show that the leading facts made known by palæontology could be explained by his theory of descent with modification through natural selection. New species had slowly come in, as old ones had slowly died out. Once the thread of succession had been broken it was never taken up again; an extinct species or group never reappeared, yet extinction was a slow and unequal process, and a few descendants of ancient types might be found lingering in protect. ed and isolated situations. "Wecan understand how it is that all the forms of life, ancient and recent, make together one grand system; for all are connected by generation. From the continued tendency to divergence, the more ancient a form is, the more generally it differs from those now living. The inhabitants of each successive period in the world's history have beaten their predecessors in the race for life, and are in so far higher in the scale of nature; and this may account for that vague, yet ill-defined sentiment, felt by many palæontologists, that organization on the whole has progressed. If it should hereafter be proved that ancient animals resemble to a certain extent the embryos of more recent animals of the same class, this fact will be intelligible."

Again, what a flood of fresh light was poured upon geological inquiry by the two chapters on Geographical Distribution in the Origin of Species! A new field of research, or, at least, one in which comparatively little had been yet attempted, was there opened out. The grouping of living organisms over the globe was now seen to have the most momentous geological bearings. Every species of plant and animal must have had a geological history, and might be made to tell its story of the changes of land and sea.

In fine, the spirit of Mr. DARwin's teaching may be traced all through the literature of science, even in departments which he never himself entered. No branch of research has benefited more from the infusion of this spirit than geology. Timehonored prejudices have been broken down, theories that seemed the most surely based have been reconsidered, and, when found untenable, have been boldly discarded. That the Present must be taken as a guide to the Past, has been more fearlessly asserted than ever. And yet it has been recognized that the present differs widely from the past, that there has been a progress everywhere, that Evolution and not Uniformitarianism has been the law by which geological history has been governed. For the impetus with which these views have been advanced in every civilized country, 
we look up with reverence to the loved and immortal name of CharLes DARWIN.

\section{WORK IN BOTANY.}

BY W. T. THISELTON DYER, F.R.S.

In attempting to estimate the influence which Mr. 'DARwIN's writings have exerted on the progress of botanical science, we must necessarily discriminate between the indireet effect which his views have had on botanical research generally, and the direct results of his own contributions. No doubt in a sense the former will seem in the retrospect to overshadow the latter. For in his later writings Mr. Darwin was content to devote himself to the consideration of problems which, in a limited field, brought his own theoretical views to a detailed test, and so may ultimately seem to be somewhat merged in them. Yet these writings can never fail to command our admiration even viewed apart from all else that Mr. DARWIN did. It is wonderful enough that so great a master in biological science should, at an advanced age, have been content to work with all the fervor and assiduity of youth at phenomena of vegetable life apparently minute and of the most special kind. To him, no doubt, they were not minute, but instinct with a significance that the professed botanical world had for the most part missed seeing in them failing the point of view which Mr. DARwIN himself supplied. It is not too much to say that each of his botanical investigations, taken on its own merits, would alone have made the reputation of any ordinary botanist.

Mr. DARWIN's attitude toward botany, as indeed to biological studies generally, was, it should always be remembered, in his early life essentially that of a naturalist of the school of Linnaus and Humbold - a point of view unfortunately now perhaps a little out of fashion. Nature in all its aspects spoke to his feelings with a voice that was living and direct.
The wr'ter of these lines can well remember Mr. DARwIN gently complaining that some of this warm enthusiasm for nature, as it presents itself unanalysed to ordinary healthy vision, seemed to be a little dulled in the younger naturalists of the day. The pages of the Journal of Researches show no such restraint, but abound with passages in which Mr. DARwIn's. unstudied and simple language is carried by the force of warm impression and perfect joy in nature to a level of singular beauty. One passage may be quoted as an illustration; it is from the description of Bahia in chapter xxi:

"When quietly walking along the shady pathways, and admiring each successive view, I wished to find language to express my ideas. Epithet after epithet was found too weak to convey to those who have not visited the intertropical regions, the sensation of delight which the mind experiences. I have said that the plants in a hothouse fail to communicate a just idea of the vegetation, yet I must recur to it. The land is one great wild, untidy, luxuriant hothouse, made by nature for herself, but taken possession of by man, who has studded it with gay houses and formal gardens. How great would be the desire in every admirer of nature to behold, if such were possible, the scenery of another planet! Yet to every person in Europe, it may be truly said, that at the distance of only a few degrees from his native soil, the glories of another world are opened to him. In my last walk I stopped again and again to gaze on these beauties, and endeavored to fix in my mind forever, an impression which at the time I knew sooner or later must fail. The form of the orange-tree, the cocoanut, the palm, the mango, the treefern, the banana, will remain clear and separate; but the thousand beauties which unite these into one perfect scene must fade away; yet they will leave, like a tale heard in childhood, a picture full of indistinct, but most beautiful figures." 
A spirit such as this, penetrating an intelligence such as Mr. D $\mathrm{D}_{\text {ArwiN's, }}$ would not content itself with the superficial interest of form and color. These, in his eyes, were the outward and visible signs of the inner secrets. The fascination of sense which the former imposed upon him but stimulated his desire to unveil the latter. In the Galapagos we are not then surprised to find him ardently absorbed in the problems which the extraordinary distribution of the plants, no less than of other organisms presented:- "I indiscriminately collected," he says, "everything in flower on the different islands, and fortunately kept my collections sep. arate.'

After tabulating the results which they yielded after systematic determination, he proceeds:

"Hence we have the truly wonderful fact, that in James Island, of the thirty-eight Galapageian plants, or those found in no other part of the world, thirty are exclusively confined to this one island; and in Albemarle Island, of the twenty-six aboriginal Galapageian plants, twenty-two are confined to this one island, that is, only four are known to grow on the other islands of the Archipelago ; and so on, as shown in the above table, with the plants from Chatham and Charles Island."

It is impossible in reading the Origin of Species not to perceive how deeply Mr. DARwin had been impressed by the problems presented by such singularities of plant distribution as he met with in the Galapagos. And of such problems up to the time of its publication no intelligible explanation had seemed possible. SIR JosepH Hooker had indeed prepared the ground by bringing into prominence, in numerous important papers, the no less striking phenomena which were presented when the vegetation of large areas came to be analysed and compared. No one therefore could estimate more justly what $\mathrm{Mr}$. D ARwIN did for those who worked in this field. How the whole theory of the geographical distribution of plants stood after the publication of the Origin of Species cannot then be better estimated than from the summary of the position, contained in Sir Joseph Hooker's recent Address to the Geographical Section of the meeting of the British Association at York

"Before the publication of the doctrine of the origin of species by variation and natural selection, all reasoning on their distribution was in subordination to the idea that these were permanent and special creations; just as, before it was shown that species were often older than the islands and mountains they inhabited, naturalists had to make their theories accord with the idea that all migration took place under existing conditions of land and sea. Hitherto the modes of dispersion of species, genera and families had been traced, but the origin of representative species, genera, and families, remained an enigma; these could be explained only by the supposition that the localites where they occurred presented conclitions so similar that they favored the creation of similar organisms. But this failer account for representation occurring in the far more numerous cases where there is no discoverable similarity of physical conditions, and of their not occurring in places where the conditions are similar. Now under the theory of modification of species after migration and isolation, their representation in distant localities is only a question of time and changed physical conditions. In fact, as Mr. DARwin well sums up, all the leading facts of distribution are clearly explicable under this theory; such as the multiplication of new forms, the importance of barriers in forming and separating zoological and botanical provinces; the concentration of related species in the same area; the linking together under different latitudes of the inhabitants of the plains and mountains, of the forests, marshes, and deserts, and the linking of these with the 
extinct beings which formerly inhabited the same areas; and the fact of different forms of life occurring in areas having nearly the same physical conditions."

If Mr. DARwIN had done no more than this for botanical science he would have left an indelible mark on its progress. But the consideration of the vario:s questions which the problem of the origin of species presented led him into other inquiries in which the results were scarcely less important. The key-note of a whole series of his writings is struck by the words with which the eighth chapter of the Origin of Species commences:

"The view generally entertained by naturalists is that species, when intercrossed, have been specially endowed with the quality of sterility, in order to prevent the confusion of all organic forms."

The examination of this principle necessarily obliged him to make a profound study of the conditions and limits of sterility. The results embodied in his well-known papers on dimorphic and trimorphic plants afforded an absolutely conclusive proof that sterility was not inseparably tied up with specific divergence. But the question is handled in the most cautious way, and when the reader of the chapter on hybridism arrives at the concluding words, in which Mr. DARWIN declares that on this ground "there is no fundamental distinction between species and varieties," he finds himself in much the same intellectual position as is produced by the Q.E.D. at the end of a geometrical demonstration.

It was characteristic of Mr. DARwis's method of study to follow up on its own account, as completely as possible, when opportunity presented, any side issue which had been raised apparently incidentally in other discussions. Indeed, it was never possible to guess what amount of evidence Mr. Darwin had in reserve behind the few words which marked a mere step in an argument. It is from his practice of bringing out from time to time the contents of his unseen treasure-house that we gain some insight into the sciertific fertility of his later years, at first sight so inexplicably prolific. Many of his works published during that period may be properly regarded in the light of disquisitions on particular points of his great theory. The researches on the sexual phenomena of heterostyled plants, alluded to above, which were communicated to the Linnean Society in a series of papers ranging over the years 1862-8, ultimately found their complete development in the volume On the Different Forms of Flowers on Plants of the same Species, published in 1877. In the same way, the statement in the Origin of Species, that "the crossing of forms only slightly differentiated favors the vigor and fertility of their offspring," finds its complete expansion in The Effects of Cross and Self-Fertilization in the Vegetable Kingdom, published in 1876.

The Origin of Species in the form in which it has become a classic in scientific literature was originally only intended as a preliminary précis of a vast accumulation of facts and arguments which the author had collected. It was intended to be but the precursor of a series of works in which all the evidence was to be methodically set out and discussed. Of this vast undertaking only one portion, the Variation of Plants and Animals under Domestication, was ever actually published. Apart from its primary purpose it produced a profound impression, especially on botanists. This was partly due to the undeniable force of the argument from analogy stated in a sentence in the introduction: "Man may be said to have been trying an experiment on a gigantic scale; and it is an experiment which nature, during the long lapsc of time, has incessantly tried." But it was still more due to the unexpected use of the vast body of apparently trivial facts and observations which Mr. DARwis with astonishing industry had disinterred from weekly 
journals and ephemeral publications of all sorts and unexpectedly forced into his service. Like Molı́̇e's Mon. sieur Jourảain, who was delighted to find that he had been unwittingly. talking prose all his life, horticultur ists who had unconsciously molded plants almust at their will at the impulse of taste or profit were at once amazed and charmed to find that they had been doing scientific work and helping to establish a great theory. The criticism of practical men, at once most tenacious and difficult to meet, was disarmed; these found themselves hoisted with their own petard. Nor was this all. The exclusive province of science was in biological phenomena forever broken down; every one whose avocations in life had to do with the rearing or use of living things, found himself a party to the "experiment on a gigantic acale," which had been going on ever since the human race withdrew for their own ends plants or animals from the feral and brought them into the domesticated state.

Mr. Darwin with characteristic modesty had probably underrated the effect which the Origin of Species would have as an argumentative statement of his views: When he came to realize this, it probably seemed to him unnecessary to submit to the labor of methodizing the vast accumulations which he had doubtless made for the second and third. installments of the detailed exposition of the evidence which he had promised. As was hinted at the commencement, his attention was rather drawn away from the study of evidence already at the disposal of those who cared to digest and weigh it, to the exploration of the field of nature with the new and penetrating instrument of research which he had himself forged. Something too must be credited to the intense delight which he felt in investigating the phenomena of living things. But he doubtless saw that the work to be done was to show how morphological and physiological complexity found its explanation from the principle of natural selection. This is the idea which is ever dominant. Thus he concludes his work on climbing plants: "It has often been vaguely asserted that plants are distinguished from animals by not having the power of movement. It should rather be said that plants acquire and display this power only when it is of some advantage to them; this being of comparatively rare occurrence, as they are aftixed to the ground, and food is brought to them by the air and rain." The diversity of the power of movement in plants naturally engaged his attention, and the last but one of his works-in some respects perhaps the most remarkable of his botanical writings-was devoted to showing that this diversity could be regarded as derived from a single fundamental property: "All the parts or organs of every plant while they continue to grow... are continually circumnutating." Whether this masterly conception of the unity of what has hitherto seemed a chaos of unrelated phenomena will be sustained time alone will show. But no one can doubt the importance of what $\mathrm{Mr}$. DARIvin has done in showing that for the future the phenomena of plant movement can and indeed must be studied from a single point of view.

Along another line of work $\mathrm{Mr}$. DARwin occupied himself with showing what aid could be given by the principle of natural selection in explaining the extraordinary structural variety exhibited by plant morphology. The fact that cross-fertilization was an advantage, was the key with which, as indicated in the pages of the Origin of Species, the bizarre complexities of orchid flowers could be unlocked. The detailed facts were set out in a well-known work, and the principle is now generally accepted with regard to flowers generally. The work on insectivorous plants gave the results of an exploration similar in its object, and bringing under one common physiological point of view a variety of the most diverse and 
most remarkable modifications of leafform.

In the beginning of these remarks the attempt has already been made to do justice to the mark Mr. DARwin has left on the modern study of geographical botany (and that implies a corresponding influence on phytopalæontology). To measure the influence which he has had on any other branches of botany, it is sufficient to quote again from the Origin of Species: "The structure of each part of each species, for whatever purpose used, will be the sum of the many inherited changes through which the species has passed during its successive adaptations to changed habits and conditions of life." These words may almost be said to be the key-note of SACHs's well-known textbook, which is the most authoritative modern exposition of the facts and principles of plant-structure and function; and there is probably not a botanical class-room or work-room in the civilized world where they are not the animating principle of both instruction and research.

Nothwithstanding the extent and variety of his botanical work, $\mathrm{Mr}$. DARwiN always disclaimed any right to be regarded as a professed botanist. He turned his attention to plants doubtless because they were con. venient objects for studyying organic phenomena in their least complicated forms; and this point of view, which, if one may use the expression without disrespect, had something of the amateur about it, was in itself of the greatest importance. For, from not being, till he took up any point, familiar with the literature bearing on it, his mind was absolutely free from any prepossession. He was never afraid of his facts or of framing any hypothesis, however startling, which seemed to explain them. However much weight he attributed to inheritance as a factor in orgauic phenomena, tradition went for nothing in studying them. In any one else such an attiunde would have produced much work that was crude and rash. But Mr.
DARWIN - if one may venture on language which will strike no one who had conversed with him as overstrained-seemed by gentle persuasion to have penetrated that reserve of nature which baftles smaller men. In other words, his long experience had given him a kind of instinctive insight into the method of attack of any biological problem, however unfamiliar to him, while he rigidly controlled the fertility of his mind in hypothetical explanations by the no less fertility of ingeniously-devised experiment. Whatever he touched, he was sure to draw from it something that it had never before yielded, and he was wholly free from that familiarity which comes to the professed student in every branch of science, and blinds the mental eye to the significance of things which are overlooked because always in view.

The simplicity of Mr. Darwin's character pervaded his whole method of work. Alphonse de Candolle visited him in 1880 and felt the impression of this: "He was not one of those who would construct a palace to lodge a laboratory. I sought out the greenhouse in which so many admirable experiments had been made on hybrids. It contained nothing but a vine." There was no affectation in this. Mr. DARwin provided himself with every resource which the methods of the day or the mechanical ingenuity of his sons could supply, and when it had served its purpose it was discarded. Nor had he any prepossession in favor of one kind of scientific work more than another. His scientific temperament was thoroughly catholic and sympathetic to anything which was not a mere regrinding of old scientific dry bones. He would show his visitors an Epipactis which for years came up in the middle of one of his gravel walks with almost as much interest as some new point which he had made out in a piece of work actually in hand. And though he had long abandoned any active interest in systematic work, 
only a few months before his death he had arranged to provide funds for the preparation of the new edition of Steudel's Nomenclator, * which, at his earnest wish, has been projected at Kew.

\section{WORK IN ZOOLOGY.}

BY G. J. ROMANES, F.R.S.

The influence which our great naturalist has exerted upon zoology is unquestionably greater than that which has been exerted by any other individual; and as it depends on his generalizations much more than upon his particular researches, we may best do justice to it by taking a broad view of the effects of Darwinism on zoology, rather than by detailing those numberless facts which have been added to the science by the ever vigilant observations of $D_{A R W I N}$. Nevertheless, we may begin our survey by enumerating the more important results of his purely zoological work, not so much because these have been rarely equaled by the work of any other zoologist, as because we may thus give due prominence to the remarkable association of qualities which was presented by Mr. DARwiN's mind. This association of qualities was such that he was able fully to appreciate and successfully to cultivate every department and ramification of biological research-whether morphological, physiological, systematic, descriptive, or statistical-and at the same time to rise above the minutice of these various branches, to take those commanding views of the whole range of nature and of natural science which have produced so enormous a change upon our means of knowledge and our modes of thought. No laborer in the field of science has ever plodded more patiently through masses of small de-

\footnotetext{
* An enumeration of the names and synonyms of all described flowerings plants with their native countries.
}

tail ; no master-mind on the highest elevation of philosophy has ever grasped more world-transforming truth.

Taking the purely zoological work in historical order, we have first to consider the observations made during the voyage of the Beagle. These, however, are much too numerous and minute to admit of being here detailed. Among the most curious are those relating to the scissor-beak bird, niata cattle, aëronaut spiders, upland geese, sense of sight and smell in vultures; and among the most important are those relating to the geographical distribution of species. The results obtained on the latter head are of peculiar interest, inasmuch as it was owing to them that Mr. Darwin was first led to entertain the idea of evolution. As displaying the dawn of this idea in his mind we may quote a passage or two from his Voyage of a Naturalist, where these observations relating to distribution are given :

"These mountains (the Andes) have existed as a great barrier since the present races of animals have appeared, and therefore, unless we suppose the same species to have been created in two different places, we ought not to expect any closer similarity between the organic beings on the opposite sides of the Andes, than on the opposite shores of the ocean."

"The natural history of these islands (of the Galapagos Archipelago) is eminently curious, and well deserves attention. Most of the organic productions are aboriginal creations, found nowhere else; there is even a difference between the inhabitants of the different islands; yet all show a marked relationship with those of America, though separated from that continent by an open space of ocean between 500 and 600 miles in width. The Archipelago is a little world within itself, or rather a satellite attached to America, whence it has derived a few stray colonists, and has received the general character of its 
indigenous produotions. Considering the small size of the islands, we feel astonished at the number of their aboriginal beings, and at their confined range. Seeing every height crowned with its crater, and the boundaries of most of the lavarstreams still distinct, we are led to believe that within a period geologically recent, the unbroken ocean was here spread out. Hence, both in space and time, we seem to be brought somewhat near to that fact-that mystery of mysteries - the first appearance of new beings on this earth."

Next in order of time we have to notice the Monograph of the Cirripedia. This immensely elaborate work was published by the Ray So ciety in two volumes, comprising together over 1,000 large octavo pages, and 40 plates. These massive books (which were respectively published in 1851 and 1854) convey the results of several years of devoted inquiry, and are particulariy interesting, not only on account of the intrinsic value of the work, but also because they show that Mr. DaRwin's powers of research were not less remarkable in the direction of purely anatomical investigation than they were in that of physiological experiment and philosophical generalization. No one can even glance through this menoir without perceiving that if it had stood alone it would have placed its author in the very first rank as a morphological investigator. The prodigious number and minute accuracy of his dissections, the exhaustive detail with which he worked out every branch of his subject-sparing no pains in procuring every species that it was possible to procure, in collecting all the known facts relating to the geographical and geological distribution of the group, in tracing the complicated history of metamorphoses represented by the in dividuals of the sundry species, in disentangling the problem of the homologies of these perplexing animals, etc.-all combine to show that had Mr. Darwin chosen to devote himself to a life of purely morpholog- ical work, his name would probably have been second to none in that department of biology. We have to thank his native sagacity that such was not his choice. Valuable as without any question are the results of the great anatomical research which we are considering, we cannot peruse these thousand pages of closely-written detail without feeling that, for a man of Mr. Darwin's exceptional powers, even such results are too dearly bought by the expenditure of time required for obtaining them. We camnot, indeed, be sorry that he engaged in and completed this solid piece of morphological work, because it now stands as a monument to his great ability in this direction of inquiry; but at the same time we feel sincerely glad that the conspicuous success which attended the exercise of such ability in this instance did not betray him into other undertakings of the same kind. Such undertakings may suitably be left to establish the fame of great though lesser men; it would have been a calamity in the history of our race if Charles DARwIN had been tempted by his own ability to become acomparative anat omist.

But as we have said-and we repeat it lest there should be any possibility of mistaking what we mean-the results which attended this laborious inquiry were of the highest importance to comparative anatomy, and of the highest interest to comparative anatomists. The limits of this article do not admit of our giving a summary of these results, so we shall only allude to the one which is most important. This is the discovery of "Complemental Males." The manner in which this discovery was made in its entirety is of interest, as showing the importance of remembering apparently insignificant observations which may happen to be incidentally made during the progress of a research. For Mr. DARwIN writes :

"When first dissecting Scalpellum vulgare, I was surprised at the almost constant presence of oue or more very 
minute parasites, on the margins of both scuta, close to the umbones. I carelessly dissected one or two specimens, and concluded that they belonged to some new class or order among the Articulata, but did not at the time even conjecture that they were Cirripedes. Many months afterward, when I had seen in Ibla that an hermaphrodite could have a complemental male, I remembered that I had been surprised at the small size of the vesiculæ seminales in the hermaphrodite $S$. vulgare, so that I resolved to look with care at these parasites; on doing so I now discovered that they were Cirripedes, for I found that they adhered by cement, and were furnished with prehensile antennæ, which latter, I observed with astonishment, agreed in every minute character, and in size, with those of $S$. vulgare. I also found that these parasites were destitute of a mouth and stomach; that consequently they were short-lived but that they reached maturity; and that all were males. Subsequently five other species of the genus Scalpellum were found to present more or lsss closelyanalogous phenomena. These facts, together with those given under Ibla (and had it not been for this latter genus, I never probably should have struck on the right line in my investigation), appear sufficient to justify me in provisionally considering the truly wonderful parasites of the several species of Scalpellum, as Males and Complemental Males." (vol. i. pp. 292-3).

The remarkable phenomena of sexuality in these animals is summed up thus:

"The simple fact of the diversity in the sexual relations displayed within the limits of the genera Ibla and Scalpellum, appears to me eminently curious. We have (1) a female, with a male (or rarely two) permanently attached to her, protected by her, and nourished by any minute animals which may enter her sac ; (2) a female, with successive pairs of short-lived males, destitute of mouth and stom- ach, inhabiting the pouches formed on the under sides of her two valves; (3) an hermaphrodite, with from one or two, up to five or six, similar short-lived males without mouth or stomach, attached to one particular spot on each side of the orifice of the capitulum; and (4) hermaphrodites, with occasionally one, two, or three males, capable of seizing and devouring their prey in the ordinary Cirripedal method, attached to two parts of the capitulum, in both cases being protected by the closing of the scuta."

With reference to these Complemental Males (so-called " to show that they do not pair with a female, but with a bisexual individual.") Mr. DARwIN further observes: "Nothing strictly analogous is known in the animal kingdom; but amongst plants, in the Linnean class Polygamia, closely similar instances abound;" and also that "in the series of facts now given we have one curious illustration more to the many already known, how gradually nature changes from one condition to the other, in this case from bisexuality to unisexuality." (ii. 29).

Lastly, to give only one other quotation from this work, he writes:

"As I am summing up the singularity of the phenomena here presented, I will allude to the marvelous assemblage of beings seen by me within the sac of an Ibla quadrivalvis, namely, an old and young male, both minute, worm-like, destitute of a capitulum, with a great mouth and rudimentary thorax and limbs, attached to each other and to the hermaphrodite, which latter is utterly different in appearance and structure; secondly, the four or five free, boatshaped larvæ, with their curious prehensile antennæ, two great compound eyes, no mouth, and six natatory legs; and lastly, several hundreds of the larvæ, in their first stage of development, globular, with horn-shaped projections on their carapaces, minute single eyes, filiform antennæ, probosciform mouths, and only three pairs of natatory legs. What diverse 
beings, with scarcely anything in common, and yet all belonging to the same species!" (i. 293).

Scattered through the Origin of Species, the Variation of Plants and Animals under Domestication, and the Descent of Man, we meet with many purely zoological observations of much interest and importance as such, or apart from their bearing on the general principles and arguments for the illustration or fortification of which they are introduced. In this connection we may particularly allude to the chapters on Variability, $\mathrm{Hy}$ bridism, and Gcographical Distribution-chapters which contain such a large number of new facts, as well as new groupings of old ones, that we cannot undertake to epitomize them in a résumé of Mr. DaRwin's work so brief as the present. Nor should we forget to mention in the present connection his experimental proof of the manner in which bees make their hexagonal cells, ad of the important part played in the economy of nature by earthworms. Moreover, the hypothesis of sexual selection necessitated the collection of a large body of facts relating to the ornamentation of all classes of animals, from insects and crustacea upward; and whatever we may think about the stability of the hypothesis, there can be no question, from a zoological point of view, concerning the value of this collection of facts as such.

But without waiting to consider further the purely zoological results presented by the work before us, we must turn to consider the effects of this work upon zoological science itself. And here we approach the true magnitude of DARwir as a zoologist. Of very few men in the history of our race can it be said that they not only enlarged science, but changed it-not only added facts to the growing structure of natural knowledge, but profoundly modified the basal conceptions upon which the whole structure rested; and of no one can this be said with more truth than it can be said of Darwin. For although it is the case that the idea of evolution had occurred to other minds-in two or three instances with all the force of full convictionit is no less certainly the case that the idea proved barren. Why did it prove so? Because it had never before been fertilized by the idea of natural selection. To demonstrate, or to render sufficiently probable by inference, the fact of evolution (for direct observation of the process is from the nature of the case impossible), required some reasonable suggestion as to the cause of evolution, such as is supplied by the theory of natural selection; and when once this suggestion was forthcoming, it mattered little whether it was considered as propounding the only, the chief, or but a subordinate cause; all that was needed to recommend the evidence of evolution to the judgment of science was the discovery of some cause which could be reasonably regarded as not incommensurate with some of the effects ascribed to it. And, unlike the desperate though most laudable groupings of LAMARCK, the simple solution furnished by DARwIN was precisely what was required to give a locus standi to the evidence of descent.

But we should form a very inadequate estimate of the services rendered to science by Mr. Darwin if we were to stop here. The few general facts out of which the theory of evolution by natural selection is formed-viz. struggle for existence, survival of the fittest, and hereditywere all previously well-known facts; and we may not unreasonably feel astonished that so apparently obvious a combination of them as that which occurred to Mr. Darwin should have occurred to no one else, with the single exception of Mr. Wallace. The fact that it did not do so is most fortunate in two respects - first, because it gave Mr. DarwiN the opportunity of pondering upon the subject $a b$ initio, and next because it gave the world an opportunity of witnessing the disinterested unselfishness 
which has been so signally and so consistently displayed by both these English naturalists. But the greatness of Mr. DARwin as the reformer of biology is not to be estimated by the fact that he conceived the idea of natural selection; his claim to everlasting memory rests upon the many years of devoted labor whereby he tested this idea in all conceivable ways-amassing facts from every department of science, balancing evidence with the soundest judgment, shirking no dificulty, and at last astonishing the world as with a revelation by publishing the completed proof of evolution. Indeed, so colossal is Mr. DARwin's greatness in this respect, that we doubt whether there ever was a man so well fitted to nndertake the work which he has so successfully accomplished. For this work required not merely vast and varied knowledge of many provinces of science, and the very exceptional powers of judgment which Mr. DARwiN possessed, but also the patience to labor for many years at a great generalization, the honest candor which rendered the author his own best critic, and last, though perhaps not least, the magnanimous simplicity of character which, in rising above all petty and personal feelings, delivered a thought-reversing doctrine to mankind with as little disturbance as possible of the deeply-rooted sentiments of the age. In the chapter of accidents, therefore, it is a singularly fortunate coincidence that $M_{1}$. $D_{A R-}$ wiN was the man to whom the idea of natural selection occurred; for although in a generation or two the truth of evolution might have become more and more forced upon the belief of science, and with it the acceptance of natural selection as an. operating cause, in. our own generation this could only have been accomplished in the way that it was accomplished; we required one such exceptional mind as that of DARIVIN to focus the facts, and to show the method.

It reems almost needless to turn from this aspect of our sabjeot to enlarge upon the influence whiob $a$ general acceptance of the theory of descent has had upon biology. We do not state the case too strongly when we say that this has been the influence which has created organization out of confusion, brought the dry bones to life, and made all the previously dissociated facts of science stand up as an exceeding great army. Let any one turn to the eloquent prophecy with which the pages of the Origin of Species terminate-s prophecy which sets forth in order the transforming effect that the dootrine of evolution would in the future exert upon every department of biology-and he may rejoice to think that Mr. Darwin himself lived to see every word of that prophecy fulfilled. For where is now the "systematist ... incessantly haunted by the shadowy doubt whether this or that form be a true species?" And has it not proved that "the other and more general departments of natural history will rise greatly in interestthat the terms used by naturalists, of affinity, relationship, community of type, paternity, morphology, adaptive characters, rudimentary and aborted organs, etc, will cease to be metaphorical, and will have a plain signification?" Do we not indeed begin to feel that "we no longer look at an organic being as a savage looks at a ship, as something wholly beyond his comprehension? And when we regard every production of nature as one which has had a long history, when we contemplate every complete structure and instinct as the summing up of many contrivances, each useful to the possessor, in the same way as any great mechanical invention is the summing up of the labor, the experience, the reason, and even the blunders of numerous workmen, when we thus view each organic being," may we not now all say with Darwin, "How far more interesting-I speak from experience--does the study of natural history become?" And may we not now all seo that "a grand and almost 
watrodden field of inquiry on the laws / the last two-and-twenty years has in of variation, on correlation, on the so astonishing a measure verified the effects of use and disuse, on the direct prophecy of the Origin of Species, action of external conditions" has surely, in conclusion, we are more been opened up; that our classifica- than ever constrained to agree with tions have become "as far as they the sentiments expressed by its closcan be made so, genealogies, and truly ing words : "When I view all beings, give what may be called a plan of not as special creations, but as the creation;" that rules of classifying lineal descendants of some few beings do "become simpler when we have a definite object in view ;" and that "aberrant species, which may fancifully be called living fossils," actually are of service in supplying " a picture of ancient forms of life?" And again, must we not agree that "when we can feel assured that all the individuals of the same species and all the closely-allied species of most genera, have, within a not very remote period, descended from one parent, and have migrated from some one birthplace; and when we better know the many means of migration, then, by the light which geology now throws, and will continue to throw, on former changes of climate and of the level of the land, we shall surely be able to trace in an admirable manner the former migrations of tho inhabitants of the whole world"? And who is now able to question that "by comparing the differences between the inhabitants of the sea on the opposite sides of a continent, and of the various inhabitants on that continent in relation to their apparent means of migration, some light can be thrown on ancieut geography" ? Or, if we turn to "the noble science of geology," do we not see that we are beginning to "gauge with some security the duration of intervals by a comparison of the preceding and succeeding forms of life"? And last, though not least, have we not found this one short sentence so charged with meaning that anew and extensive science, second in importance to none, may be almost said to have grown out of what it states : "Embryology vill often reveal to us the structure, in some degree obscured, of the proto"ypes"? which lived long before the first bed of the Cambrian system was deposited, they seem to me to become ennobled ... There is grandeur in this view of life, with its several powers, having been originally breathed by the Creator into a few forms or into one; and that, whilst this planet has gone cycling on according to the fixed law of gravity, from so simple a beginning endless forms most beautiful and most wonderful have been, and are being evolved."

\section{WORK IN PSYCHOLOGY.}

BY G. J. ROMANES, F.R.A.

The effects upon Psychology of Mr. DARwen's writings have been so immense, that we shall not overstate them by saying that they are fully comparable with those which we have previously considered as having been exerted by the same writings on geology, botany, and zoology. This fact at first sight can searcely fail to strike us as remarkable, in view of the consideration that Mr. DarwIN was not only not himself a psychologist, but had littlo aptitude for, and perhaps less sympathy with, the technique of psychological method. The whole constitution of his mind was opposed to the subtlety of the distinotions and the mysticism of the conceptions which this technique so frequently involves; and therefore he was accustomed to regard the problems of mind in the same broad and general light that he regarded all the other problems of nature. But if at first sight we are inclined to feel surprised If the progress of srienas during that, although possessing none of the 
special mental equipments of a psychologist, he should have exerted so enormous an influence upon psychology, our surprise must vanish when we consider the matter a little more attentively. For the truth of this matter is that psychology, in being the science furthest removed from the reach of experimental means and inductive method, is the science which has longest remained in the trammels of a priori analysis and metaphysical thought; therefore $D_{A R-}$ wIN, by casting the eye of a philosophical naturalist upon the facts, without reference to the cobwebs which the specialists had woven around them. was able to gather directly much new information as to their meaning. And the rare sagacity with which he observed and reflected upon the phenomena of mind merely as phenomena or facts of nature, led to the remarkable results which we shall presently have to consider-results which have done more than any other to unmuftle the young science of psychology from the swaddling clothes of its mediæval nursery.

The portions of Mr. Darwin's writings which refer to mental science are very limited in extentcomprising, in fact, only one chapter in the Origin of Species, three in the Descent of Man, and a short paper on the development of infantile intelligence. The importance of the effect produced by them is therefore rendered all the more remarkable; but in this connection it seems desirable to state that the chapters to which we have alluded represent, in an exceedingly condensed form, the result of extensive thought and reading. A year or two ago Mr. DARwin lent the present writer the original drafts of these essays, together with all the notes and memoranda which he had collected on psychological subjects during the previous forty years, and so we can testify that any one who reads these MSS. is more likely to be surprised at the amount of labor which they indicate than at the effect which has been produced by the compressed publication of its results. What strikes one most in reading the MSS. is that which also strikes one most in reading the published résumé that has grown out of them-namely, the honest adherence throughout to the strictly scientific, or, as the followers of Comte would say, positive method. of seeking and interpreting facts; speculation, hypothesis, and strawsplitting are everywhere, not so much intentionally avoided, as alien to the whole conception of the manner in which the sundry problems are to be attacked. We all know that this conception has not met with universal approval-that more than one writer, adhering to the traditional methods: of psychological inquiry, has express-ly joined issue upon it. But although. it is an easy matter for a technical psychologist to point to an absence of technical thought, and so of a recognition of technical principles, in these parts of Mr. DARWIN's writings, we are persuaded that the exposê only serves to reveal a beam in the eye of the technical psychologist which prevents him from seeing clearly how to remove the mote from $\mathrm{Mr}$. $\mathrm{D}_{\mathrm{AR}}$. wIN's. In other words, although it is true that Mr. DarwIN does not recognize the niceties of distinction which seem so important to what we may term the professional mind, it is no less true that in the cases to. which we have alluded, the professional mind has failed in its duty of filling up for itself the technical lacunoe in Mr. DarwIN's expositions. Such lacunce no doubt occur, but they neverreally vitiate the integrity of the conclusions; and a trained psychologist would best fulfill his function as an under-builder, by supplying here and there the stones which the hand of the master has neglected to put in. To ourselves it always seems one of the most wonderful of the many wonderful aspects of Mr. DARwIN's varied work, that by the sheer force: of some exalted kind of common sense, unassisted by any special acquaintance. with psychological method, he should 
have been able to strike, as it were, straight down upon some of the most important truths which have ever been brought to light in the region of mental science. These we shall now proceed to consider.

The chapter in the Origin of Species to which we have referred, is occupied chiefly with an application of the theory of natural selection to the phenomena of instinct, and in our opinion it has done more than all other psychological writings put together to explain what instinet is, why it is and how it came to be. Before this chapter was published, the only scientific theory concerning the origin of instincts that had been formed was the theory which regarded them as hereditary habits. Because we know that in the individual intelligent adjustments become, by frequent repetition, automatic, it was inferred that the same might be true of the species, and therefore that all instincts were to be regarded as what Lewes has aptly termed "lapsed intelligence." In this view there is, without any question, much truth, and the first thing we have to notice about Mr. DARwIN's writings with reference to instinct is that they not only recognized this truth, but, by elucidating the whole subject of heredity, placed it in a much clearer light than it ever stood before. Mr. DARwin, however, carried the philosophy of the subject very much further when he agued that, in conjunction with the cause formulated as "lapsing intelligence," there was another at least as potent in the formation of instinctsnamely, natural selection. His own statement of the case is so terse that we cannot do better than quote it.

"If Mozart, instead of playing the pianoforte at three years with wonderfully little practice, had played a tune with no practice at all, he might truly be said to have done so instinctively. But it would be a serious error to suppose that the greater number of instincts have been acquired by habit in one generation, and then transmitted by inheritance to succeed- ing generations. It can be clearly shown that the most wonderful in stincts with which we are acquainted, namely, those of the hive-bee and of many ants, could not possibly have been acquired by habit.*

"It will be universally admitted that instincts are as important as corporeal structures for the welfare of each species, under its present conditions of life. Under changed conditions of life, it is at least possible that slight modifications of instinct might be profitable to a species ; and if it can be shown that instincts do vary ever so little, then I can see no difficulty in natural selection preserving and continually accumulating variations of instinct to any extent that was profitable. It is thus, I believe, that all the most complex and wonderful instincts have originated."

Briefiy, then, in Mr. DARwrn's view, instincts may arise by lapsing intelligence, by natural selection of accidental and possibly non-intelligent variations of habit, or by both principles combined-seeing that "a little dose of judgment" is often commingled with even the most fixed (or most strongly inherited) instincts. One good test of the truth of the view as a whole is that which Mr. Darwin has himself supplied-namely, searching through the whole range of instincts to see whether any occur which are either injurious to the animals exhibiting them, or benefical only to other animals. Now there is really no authentic case of the former, and the latter are so few in number that they may reasonably be regarded, either as rudiments of instincts once useful (so analogous to the human tail), or as still useful in some unobservable manner (so analogous to the tail of the rattlesnake). The case of aphides secreting honey-

* Because the individuals which exhibit them, being neuters, can never have progeny. It is indeed surprising, as Mr. DARWIN further on observes, that no one previously " advanced this demonstrative case of neuter insects against the well-known doctrine of inherited habit as advanced by LAMARCK." 
dew for the benefit of ants occurred to Mr. Darwix as one which might be adduced against his theory in this connection, and he therefore made some experiments upon the subject, which led him to conclude that "as the excretion is extremely viscid, it is no doubt a convenience to the aphides to have it removed; therefore proba bly they do not excrete solely for the good of the ants."

A discussion of the variability of instinct, and of the probability that variations should be inherited, leads him to consider the important case of the apparent formation of artificial instincts in our domestic dogs by contiuued training with selection, and also the not less important case of the effects produced upon natural instincts by the long-continued change of environment to which other of our domestic animals have been exposed. All the facts adduced as resulting from these long-continued though unintentional experiments by man, go to substantiate, in a very unmistakable manner, the theory concerning the origin and development of instincts which we are considering. The chapter concludes with a close cohsideration of some of the more remarkable instincts which occur in the animal kingdom, such as the parasitic instinct of the cuckoo, the slave. making instinct of ants, and the cellmaking instinct of bees. A flood of light is thrown upon the latter, and the old standing problem as to how the bees have come to make their cells in the form which requires the smallest amount of material for their construc. tion, while affording the largest capacity for purposes of storage, is solved.

From this brief account of the chapter on "Instinct," it is evideut that the new idea which it starts, and in several directions elaborates, is an idea of immense importance to psychology, and that the broad marks or general principles laid down by it afford large scope for a further fillingin of numberless details by the attentive observation of facts. The phe- nomena of instinct, indeed, cerse to be rebellious to explanation, and range themselves in orderly array under the flag of science.

But not less important than the chapter on "Instinct" are the chapters in the Descent of Man on the mental powers of man as compared with those of the lower animals, on the moral sense, and on the development of both during primæval and civilized times. Our estimate of the value of these chapters is so high that we gladly endorse the opinion of the late Prof. Clifford-who was no mean judge upon such matters-when he writes of them as presenting to his mind "the simplest, and clearest, and most profound philosophy that was ever written upon the subject." As the three chapters together cover only eighty pages, it seems needless to render an abstract of them, so we shall only observe that although it is easy to show in them, as Mr. Mrvarr and others have shown, a want of appreciation of technical terms, and even of Aristotelian ideas, nowhere in the whole range of $\mathrm{Mr}$. Darwis's writings is his immense power of judicious generalization more conspicuously shown. So much is this the case, that in studying these chapters we have ourselves always felt glad that Mr. DARwrr was not the specialist in psychology which some of his critics seem to suppose that he ought to have been if he presumed to shake their science to its base; had he been such a specialist the great sweep of his thought might have been hindered by comparatively immaterial details.

Of the three chapters which we are considering, the most important is the one on the moral sense. As he himself says:

"This great question (the origin of the moral sense) has been discussed by many writers of consummate ability; and my only exeuse for touching upon it, is the impossibility of here passing it over; and because, so far as I know, no one has approached it exclusively from the side of natural 
bistory. The investigation possesses, also, some independent interest, as an attempt to see how far the study of the lower animals throws light on one of the highest psychical faculties of man."

The result of this investigation and study has been to give, if not a new point of departure to the science of ethics, at least a completely new conception as to the origin of the faculties with which that science has to deal; and without attempting to discuss the objections which havo been raised against the doctrine, or to enumerate the points of contact between this doctrine and older ethical theoriesto neither of which undertakings would our present space be adaptedwe may say in general, that, as in the case of instinct, so in that of conscience, we feel persuaded that $\mathrm{Mr}$. DARwin's genius has been the first to bring within the grasp of human understanding large classes of phenomena which had been previously wholly unintelligible.

"The Expression of the Emotions in Man and Animals" is an essay which may be more suitably mentioned in the present division than in any of the preceding. The work is a highly interesting one, not only on sccount of its philosophical theories, but also as an extensive accumulation of facts. "The three chief principles" enunciated by the former are: "the prineiple of serviceable associated habits" ; (2) "the principle of antithesis"; and (3) "the principle of actions due to the constitution of the Nervous System, independently from the first of the Will, and independently to a certain extent of Habit." It is shown that the first of these principles leads to the performance of actions expressive of emotions, because "certain complex actions are of direct or indirect service under certain states of mind, in order to relieve or gratify certain sensations desired, etc.; and whenever the same state of mind is induced, however feebly, there is a tendency through the force of habit and association for the same movements to be performed, though they may not then be of the least ise." The second principle arises because, "when a directly opposite state of mind is induced, there is a strong and involuntary tendency to the performance of movements of a directly opposite nature, though these are of no use; and such movements are in some cases highly expressive." And the third principle occurs because, "when the sensorium is strongly excited, nerve-force is generated in excess, and is transmitted in certain definite directions, depending on the connection of the nerve-cells, and partly on habit." All these principles are more or less well substantiated by large bodies of facts, and although the essay, from the nature of its subjectmatter, is necessarily not of so transforming a character in psychology as those which we have already considered, and although we may doubt whether it gives a full explanation of every display of expressive movement, we think there can be no reasonable question that the three principles above quoted are shown to be true principles, and therefore that the essay is completely successful within the scope of its purposes.

Lastly, we have to allude to the brief paper published in Mind on the psychogenesis of a child. These notes were not published till long after they were taken, so that Mr. DARwIN was the first observer, in a department of psychology which-owing chiefly to the attention which his other writings have directed to the phenomena of evolution-is now being very fully explored. The observations relate entirely to matters of fact, and display the same qualities of thoughtfulness and accuracy which are so conspicuous in all his other work.

On the whole, then, we must say that Mr. DARwiN has left as broad and deep a mark upon Psychology as he has upon Geology, Botany, and Zoology. Groups of facts which previously seemed to be separate, are now seen to be buund together in the most intimate manner; and some of 
what must be regaraed as the first principles of the science, hitherto unsuspected, have been brought to light. No longer is it enough to say that such and such actions are the result of instinct, and so beyond the reach of explanation; for now the very thing to be explained is the character and origin of the instinct-the causes which led to its development, its continuance, its precision and its use. No longer is it enough to consider the instincts manifested by an animal, or a group of animals, as an isolated body of phenomena, devoid of any scientific meaning because standing out of relation to any known causes; for now the whole scientific import of instincts as manifested by one animal depends on the degree in which they are connected by general principles of causation with the instincts that are manifested by other animals. And not only in respect of instincts, but also in respect of intelligence, the science of comparative psychology may be said for the first time really to have begun with the discovery of the general causes in question; while from the simplest reflex actions, up to the most recondite processes of reason and the most imperious dictates of conscience, we are able to trace a continuity of development. A revelation of truth so extensive as this in the department of science which, in most nearly touching the personality of man, is of most importance for man to explore, cannot fail to justify the anticipations of the revealer, who, in referring to psychology, could "in the future see open fields for far more important researches" than those relating to geology and biology. If the proper study of mankind is man, Mr. DARwiN has done more than any other human being to further the most desirable kind of learning, for it is through him that humanity in our generation has first been able to begin its response to the precept of antiquity-Know thyself.
The series of urief résumés whereby we have endeavored to take a sort of bird's eye view of Mr. DARwin's great and many labors have now drawn to a close. But we cannot finish this very rudimentary sketch of his work without alluding once more to what was said in the opening paragraphs of the series, and which cannot be more tersely repeated than in $\mathrm{Mr}$. DARwIN's own words there quoted with reference to Prof. Henslow: "Peflecting over his character with gratitude and reverence, his moral attributes rise, as they should do in the highest character, in pre-eminence over his intellect."

In the gratitude and reverence which we feel in a measure never to be expressed, we sometimes regret that the ill-health which led to his seclusion prevented the extraordinary beauty of his character from being more generally known by personal intercourse. True it is that the world has shown in a wonderful degree a just appreciation of this character, so that many thousands, in many nations, who had never even seen the man, heard that Charles Darwin was dead with a shock like that which follows suck an announcement in the case of a wellloved friend; still it seems almost sad that when such an exalted character has lived, it should only have been to so comparatively few of us that the last. farewell over the open grave at Westminster implied a severance of feelings which had never been formed before, and which, while ever living among the most hallowed lights of memory, we know too well can never be formed again. But to those of us who have now to mourn so unspeakable a loss, it is some consolation to think, while much that was sweetest. and much that was noblest in our lives. has ended in that death, his great life and finished work still stand before our view; and in regarding them we may almost bring our hearts to cryNot for him, but for ourselves, we weep. 


\section{ALEXANDER VON HUMBOLDT.*}

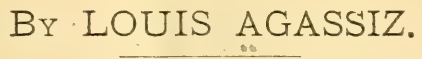

I am invited to an unwonted task. Thus far I have appeared before the public only as a teacher of Natural History. To-day, for the first time in my life, I leave a field in which I am at home, to take upon myself the duties of a biographer. If I succeed at all, it will be because I so loved and honored the man whose memory brings us together.

Alexander von Humboldt was born in Berlin in 1769,-one hundred years ago this day, -in that fertile year which gave birth to Napoleon, Welington, Canning, Cuvier, Chateaubriand, and so many other remarkable men. All America was then the property of European monarchs. The first throb of the American Revolution had not yet disturbed the relations of the mother country and her colonies. Spain held Florida, Mexico, and the greater part of South America; France owned Louisiana; and all Brazil was tributary to Portugal. What stupendous changes have taken place since that time in the political world! Divine right of possession was then the recognized law on which governments were based. A mighty Republic has since been born, the fundamental principle of which is self-government. Progress in the intellectual world, the world of thought, has kept pace with the advance of civil liberty; reference to authority has been superseded by free inquiry; and Hомвогрт was one of the great leaders in this onward

* An address delivered at the Centennial Anniversary of the birth of Alexander von Humboldt, under the auspices of the Boston Society of Natural History, (Sept. I4, I869). movement. He bravely fought the battle for independence of thought against the tyranny of authority. No man impressed his century intellectually more powerfully, perhaps no man so powerfully as he. Therefore he is so dear to the Germans, with whom many nations unite to do him honor to-day. Nor is it alone because of what he has done for science, or for any one department of research, that we feel grateful to him, but rather because of that breadth and comprehensiveness of knowledge which lifts whole communities to higher levels of culture, and impresses itself upon the unlearned as well as upon students and scholars.

To what degree we Americans are indebted to him, no one knows who is not familiar with the history of learning and education in the last century. All the fundamental facts of popular education in physical science, beyond the merest elementary instruction, we owe to him. We are reaping daily in every school throughout this broad land, where education is the heritage even of the poorest child, the intellectual harvest sown by him. See this map of the United States;-all its important traits are based upon hisinvestigations; for he first recognized the essential relations which unite the physical features of the globe, the laws of climate on which the whole system of insothermal lines is based, the relative height of mountain chains and tablelands, the distribution of vegetation over the whole earth. There is not a text-book of geography or a school-atlas in the hands of our children to-day which does not bear. 
however blurred and defaced, the impress of his great mind. But for him our geographies would be mere enumerations of localities and statistics. He first suggested the graphic methods of representing natural phenomena which are now universally adopted. The first geological sections, the first sections across an entire continent, the first averages of climate illustrated by lines, were his. Every school-boy is familiar with his methods now, but he does not know that Humboud is his teacher. The fertilizing power of a great mind is truly wonderful; but as we travel farther from the source, it is hidden from us by the very abundance and productiveness it has caused. How few remember that the tidal lines, the present mode of registering magnetic phenomena and oceanic currents, are but the application of HгмвоLDT's researches, and of his graphic mode of recording them!

This great man was a feeble child, and had less facility in his studies than most children. For this reason his early education was intrusted to private teachers, his parents being wealthy, and of a class whose means and position command the advantages denied to so many. It is worthy of note that when he was a little fellow, not more than seven years old, his teacher was CAMPE, author of the German Robinson Crusoe. We can fancy how he amused the boy with the ever fresh story of Crusoe on his desert island, and inspired him even at that early age with the passionate love of travel and adventure which was to bear such fruit in later years. Neither should we omit, in recalling memories of his childhood, his tender relation to his older brotber Williak. These two brothers, so renowned in their different departments of learning,- - the elder as statesman and philologist, the younger as a student of nature,-were united from their earliest years by an intimate sympathy which grew with their growth and strengthened with their strength. They went together to the University of Frankfort, the younger being then seventeen, W illiasr nineteen. After two years at Frankfort they went to the University of Göttingen, where they passed the two following years. In these four pregnant years of student life Arexander already sketched the plans which occupied his active mind for more than threescore years and ten.

The character of the German universities is so different from ours, that a word upon his studentlife may not be out of place here. Untrammeled by prescription and routinc, every branch of learning was open to him. Instead of being led through a prescribed course of study, an absolute freedom of selection in accordance with his natural predilections was allowed him. The effect of this is felt through his whole life; there was a universality, a comprehensiveness in his culture, which could not be obtained under a less liberal system of education.

Leaving the University at the age of twenty-one, he began to make serious preparations for the great journeys toward which all his hopes tended. Nothing has impressed me more in reviewing Нбмвоцит's life, than the harmony between the aspirations of his youth and the fulfillment of his riper age. A letter to PrAfr, written in his twenty-fourth year, contains the first outline of the Cosmos ; its last sheets were forwarded to the publisher in his ninetieth year, two months before his death. $\mathrm{He}$ had thus been an original investigator for nearly seventy years.

His first journey after leaving the University was important rather for the circumstances under which it was made than for any local interest. He went to the Rhine with Georar Forster, who had accompanied Cook in his second journey round the world. "He could hardly have been thrown with any one more likely to stimulate his desire to travel than this man, who had visited the South Seas, had seen the savages of the Pacific Islands, and had made valuable 
contributions to geographical science. / Nature in all her aspects. His desires Nor was this their only point of turned especially toward India. He sympathy. Georg Forster was a wished to visit the East, and, reachwarm republican; he had espoused ing India by way of Egypt, Syria, the ideas of the French Revolution, and Persia, to cross the Pacific and and when Mayence became united to return to Europe through America. the French Republic he was sent as In this he was foiled; but to his deputy to the National Assembly in latest day he felt the same longing Paris. Hunbond was too ardent for a sight of that antique ground of and too independent to be a laggard civilization. At this moment all in the great public questions of the Europe was in a blaze; between conday. Like Forster, he also believed tending armies there was little room in the Republic of France and in the for peaceful travel and investigation. dawn of civil liberty for Europe. Thus, both in political and scientific preferences, although so different in age, he and Forsrer were sympathetic traveling companions. This excursion was by no means a pleasure trip. Young as he was, Humbond' had knowledge enough to justify him in approaching the most difficult geological question of the day, namely, the origin of the Basalt. At that time the great war was waging be tween the Neptunists and Plutonists, - that is, between the two great schools in Geology,--one attributing the rocks to fire as the great constructive agent, the other asserting that all rocks were the result of water deposits. The young student brought to these subjects the truthfulness and patience which marked all his later investigations. Carried awayneither by theories nor by leaders, he left in abeyance the problem which seemed to him not yet solved. His interest in this and kindred topies carried him to Freiberg, where he studied Geology with WERNer, and where he made aequaintance with Leopord von Buch, who became the greatest geologist of the age, and was through life his trusted friend. $\mathrm{He}$ also applied himself to Anatoray and Physiology, and made physical investigations on the irritability of the muscular fiber, which he afterward extended to the electric fishes, during his American journey.

All the while he brooded over his schcmes of travel, gathering materials in every direction, in order that his mind might be prepared to understand We find him, therefore, floating between various plans. He went to Paris with the hope of joining $\mathrm{BAU}_{\mathrm{AU}}$ DIN's contemplated expedition to Australia. In this he was again baffled, for the breaking out of the war between France and Austria postponed the undertaking indefinitely. His next hope was Spain; he might obtain permission to visit her Transatlantic possessions and study tropical nature under the equator. Here he was successful. The scientific discoverer of America, as the Germans like to call him, was destined to start from the same shore as Christopher Conumbus. He not only received permission to visit the colonies, but special facilities for his investigations were offered him. This liberality was unexampled on the part of the Spanish government, for in those days Spain guarded her colonies with jealous exclusiveness. His enthusiasm disarmed suspicion, however, and the king cordially sustained his undertaking.

Almost ten years had passed in maturing his plans, preparing himself for their execution and obtairing the means of carrying them out. He was nearly thirty years of age when he sailed from the harbor of Corunna, running out in a dark and stormy night, and so evading the English cruisers which then blockaded the Spanish coast.

There is perhaps no part of НуMBordu's life better known to the public, especially in this country, than his American journey. His fascinating "Personal Narrative" is 
known to all, and I need not, therefore, describe his course, or dwell upon the details of his personal experience. No period of his life, how ever, has had a more powerful influence upon knowledge and education than those five years of travel, and therefore I will speak at some length of their scientific results. In the very glory of his youth, and yet with an intellectual maturity which belongs to later manhood, his physical activity and endurance kept pace with the fertility and comprehensiveness of his mind. Never was the old proverbial wish, "Si jeunesse savait, si vieillesse pouvait," so near fulfillment; never were the strength of youth and the knowledge of age so closely combined.

At the first step of the journey, namely, his pause at the Canary Islands and ascension of the Peak of "Teneriffe, he has left us a graphic picture of the place, of its volcanic phenomena, its geological character, and the distribution of its vegetation, in which are foreshadowed all his later generalizations. Landing in Cumana he made his first long station there. His explorations of the mountains, valleys, and sea-shore in that neighbborhood, his geological researches, his astronomical observations by which the exact position of various localities was determined, his meteorological investigations, and his collections of every kind, were of vast scientific importance. He had already begun his studies upon averages of climate, the result of which, known as the "isothermal lines," was one of his most original contributions to science. With the intuition of genius he saw that the distribution of temperature obeyed certain laws. $\mathrm{He}$ collected, both from his own observation and from report, all that could be learned of the average temperature in various localities, and combining all these facts he first taught geographers how to trace upon their maps those curves which give in one undulating line the varying aspects of climate upon the whole globe. His constantly able to compare my results physical experiments upon animals and plants, and his collections were also of great value. At Paris he had made the acquaintance of Bonpland, a young botanist, equally determined with himself to see distant lands, who accompanied him in his journey to South America; and when HumBoLDT was too exclusively engaged in physical experiments to join in the botanical researches, they were nevertheless not neglected, for BoNPLAND was unremitting in the study of plants and in making collections.

After months thus spent in the neighborhood of the coast, Humbold crossed the Llanos, the great plains which divide the basin of the Orinoco from the sea-shore. Here again every step of his journey is marked by original research. He has turned those desert plains into enchanted land by the power of his thought, and left us descriptions, as fascinating from their beauty as they are valuable for their novelty and precision. In his long and painful journey through the valley of the Orinoco he traced the singular network of rivers by which this great stream connects, through the Cassiquiare and the Rio Negro, with the Amazons, - a fresh-water route which is, no doubt, yet to become one of the highways of the world. Had it not been for the illiberality of the Portuguese government, he would probably have gone down the Rio Negro to the Amazons, and would perhaps have changed completely the course which he ultimately took. He was, however, turned back from the mighty river by a prohibition which made it dangerous to proceed farther on pain of imprisonment and the possible renunciation of all his cherished plans. When, in my late exploration of the Amazonian Valley, I read his narrative again, on the spot, I could not but contrast the cordial liberality which smoothed every difficulty in my path with the dangers, obstacles, and suffering which beset his. I approached, however, so near the scene of his labors that I was constantly able to compare my results 
with his, and to recognize the extent heigher.* Returning from the Anof bis knowledge and the comprehen- des, Humbond skirted the Pacific siveness of his views, even where the from Truxillo to Acapulco, and paused progress of science led to a different in Mexico again. There he ascended interpretation of the facts.

I omit all notice of his visit to Cuba, and his journey through Mexico, interesting as they were, remarking only that to him we owe the first accurate maps of those regions. So imperfect were those published before him, that even toward the close of the last century the position of Mexico differed by about three hundred miles in the maps published by different geographers. Huмвоцdт's is the first general map of Mexico and Cuba based upon astronomical observations.

The next great stage of the American journey is along the ridge of the Andes. There is a picturesque charm about this part of the undertaking which is irresistible. At that time traveling in those mountains was infinitely more difficult than it is now. We follow him with his train of mules, bearing the most delicate instruments, the most precious scientific apparatus, through the passes of the great chain. Measuring the mountains, - sounding the valleys as he went,-tracing the distribution of vegetation on slopes 20,000 feet high, - examining extinct and active volcanoes,-collecting and drawing animals and plants, - he brought away an incredible amount of information which has since filtered into all our scientific records, remodeled popular education, and become the common property of the civilized world. Many of these ascensions were attended with infinite danger and difficulty. He climbed Chimborazo to a height of 18,000 feet at a time when no other man had ever ascended so far above the level of the sea, and was prevented from reaching the summit by an impassable chasm, in which he nearly lost his life. When, a few years later, Gay-Lussac made his famous ascent in a balloon, for the sake of studying atmospheric phenomena, he rose only 1,200 feet all the great mountains in the neighborhood, continuing and completing the same investigations which he had pursued with such persistency through his whole laborious journey. He studied volcanic action, mines, the production of precious metals, their influence upon civilization and commerce, latitudes and longitudes, averages of climate, relative heights of mountains, distribution of vegetation, astronomical and meteorological phenomena. From Mexico he went to Havana, and from Havana sailed for Philadelphia. His stay in this country was short. He was cordially received by JEFFERSON on his visit to Washington, and warmly welcomed by scientific men in Philadelphia. But he made no important researches in the United States, and sailed for Europe soon after his arrival.

He returned to Paris in 1804, having been five years absent from Europe. It was a brilliant period in science, letters, and politics in the great capital. The Republic was still in existence; the throes of Revolution were over, and the reaction toward monarchical ideas had not yet culminated in the Empire. LAPLACE, Gay-Lussac, Cuvier, Desfontaines, Delambre, Oltmanns, Fourcroy, Berthollet, Biot, Dolomev, LaMARCK, and LACÉPÈDE were leaders then in the learned world. The young traveler, bringing intellectual and material treasures even to men who had grown old in research, was welcomed by all, and in this great centre of social and intellectual life he made his home for the most part, from 1805 to 1827 ; from the last days of the Republic, through the rise and fall of

* The ascension of Mont Blanc by $\mathrm{DE}$ SAUSSURE was the only exploit of that kind on record before. Even as late as 1842 the ascent of the Jungfrau attracted some attention. Nowadays tourists may run up the highest summits of the Alps to drink the health of their friends. 
the Empire, to the restoration of the Bourbons. He devoted himself to the publication of his results, and secured as his collaborators in this work the ablest men of the day. Cuvier, LATREILLE, and VALENCIENNES worked up the zoological collections, BoNPLAND and KUNTH directed the publication of the botanical treasures, OLtMANNS undertook the reduction of the astronomical and barometrical observations, while he himself jointly with Gay-Lussac and Provençal made investigations upon the respira. tion of fishes and upon the chemical constitution of the atmosphere and the composition of water, which have left their mark in the annals of chemistry. While of course superintending more or less all the publications, Humbold himself was engaged especially with those upon physical geography, meteorology, and geology. The mere enumeration of the volumes resulting from this great expedition is impressive. It embraces three folio volumes of geographical, physical, and botanical maps, including scenery, antiquities, and the aboriginal races; twelve quarto volumes of letter-press, three of which contain the personal narrative, two are devoted to New Spain, two to Cuba, two to zoology and comparative anatomy, two to astronomy, and one to a physical description of the tropies. The botanical results of the journey occupy not less than thirteen folio volumes, ornamented with magnificent colored plates. As all these works are in our Public Library in Boston, I would invite my hearers to a real intellectual treat and a gratification of their asthetic tastes, in urging them to devote some leisure hour to turning over the leaves of these magnificent volumes. A walk through the hothouses of the largest botanical garden -and unfortunately we have no such on this continent-could hardly be more impressive than an examination of these beautiful plates. Add to these a special work on the position of rocks in the two hemispheres, one on the isothermal lines, his innumera ble smaller papers, and lastly, fivo volumes on the history of geography and the progress of nautical astronomy during the fifteenth and sixteenth centuries, more or less directly connected with HuмвoLdT's own journey, though published in later years. His investigations into the history of the discovery of America have a special interest for us. We learn from him that the name of our continent was first introduced into the learned world by WALTzeEMúller, a German professor, settled at St. Didié, in Lorraine,Hruacomruds, as he called bimself at a time when scholars were wont to translate their names into the dead languages, and thought it more dignified to appear under a Greek or Latin garb. This cosmographer published the first map of the New World, with an account of the journeys of Arericus Vespuccr, whose name he affixed to the lands recently discovered. Humbold shows us, also, that Concmbus's discovery was no accident, but grew naturally out of the speculations of the time, themselves the echo of a far-off dream, which he follows back into the dimness of Grecian antiquity. We reoognize again here the characteristic features of HсмвоLDT's mind, in his constant endeavor to trace discoveries through all the stages of their progress.

Although he made his head-quarters in Paris, it became necessary for Номвогыт, during the preparation of so many extensive works, to undertake journeys in various parts of Europe; to examine and re-examine Vesuvius, and compare its mode of action, its geological constitution, and the phenomena of its ermptions with what he had seen of the volcanoes of South America. On one of these occasions he ascended Vesuvius in company with Gay-Lussac and Leopold voN Buch. That single excursion, undertaken by such men, was fruitful in valuable additions to knowledge. At other times he went to consult rare books in the great libraries of Germany and England, or to discuss with 
his brother in Berlin, or with trusted friends in other parts of Europe, the work in which he was engaged, comparing notes, assisting at new experiments, suggesting further inquiries, ever active, ever inventive, ever suggestive, erer fertile in resource, -neither disturbed by the great political commotions which he witnessed, nor tempted from his engrossing labors by the most brilliant offers of public service or exalted position. It was during one of his first visits to Berlin, where he went to consult about the organization of the University with his brother WILLIAM, then Minister of State in Prussia, that he published those fascinating "Views of Nature," in which he has given pictures of the tropics as vivid and as exciting to the imagination as if they lived on the canvas of some great artist.

The question naturally arises, Who provided for the expenses of these extensive literary undertakings? Humbold himself. No one knows exactly what he spent in the publication of his works. Some approach to an estimate may, however, be made by computing the cost of printing, paper, and engraving, which cannot have amounted to less than two hundred and fifty thousand dollars. No doubt the sale indemnified him in some degree, but all know that such publications do not pay. The price of a single copy of the complete work on America is two thousand dollars, - double that of the great national work published by France upon Egypt, for the publication of which the government spent about eight hundred thousand dollars. Of course very few copies can be sold of a work of this magnitude. But from his youth upward HurBOLDT spent his private means liberally, not only for the carrying out and subsequent publication of his own scientific undertakings, but to forward the work of younger and poorer men. The consequence was that in old age he lived upon a small pension granted to him by the King of Prussia.
His many-sideness was remarkable. $\mathrm{He}$ touched life at all points. $\mathrm{He}$ was the friend of artists, no less than of scientific and literary men. His desire to make his illustrations worthy of the great objects they were to represent brought him into constant and intimate relation with the draughtsmen and pain vers of his day. Even David did not think it below his dignity to draw an allegoric titlepage for the great work. He valued equally the society of intelligent and cultivated women, such as Madame de Stael, Madame Rècamer, Rahel, Betrina, and many others less known to fame. He was intimate with statesmen, politicians, and men of the world. Indeed, the familiarity of Humbold with the natural resources of the countries he had visited,--with their mineral products and precious metals, made his opinion valuable not only in matters of commerce, but important also to the governments of Europe; and after the colonies of South America had achieved their independence, the allied powers of Europe invited him to make a report upon the political condition of the new republics. In 1822 he attended the Congress of Verona, and visited the South of Italy with the King of Prussia. Thus his life was associated with the political growth and independence of the New World, as it was intimately allied with the literary, scientific, and artistic interests of the Old. He never, however, took an active part in politics at home, and yet all Germany looked upon him as identified with the aspirations of the liberal party, of which his brother William was the most prominent representative.

Before closing this period of HumBoLDT's life I would add a few words more in detail upon the works published by him after his return from South America. One of the first fruits in the rich harvest reaped from this expedition was the successful attempt to which I have already alluded at representing graphically the physical features of that continent. Thus far such representations 
had mainly consisted in maps and the took to represent, in like manner, the delineation of the characteristic plants internal structure of the earth, drawand animals. HuмвоцDт devised a ing similar charts upon which the new method, equally impressive to relative position of the rocks, with the eye and comprehensive in its out- signs to indicate their mineralogical lines. Impressed by the fact that character, is faithfully portrayed. The vegetation changes its character as it first chart of this kind was drawn by ascends upon the side of high mount- him in Mexico in 1804, and presented ains,-thus presenting successive ter- to the School of Mines of that city. races upon their slopes,-he conceived It was afterward published in the the idea, already suggested by his ex- Atlas of the American Journey.-We amination of the Peak of Teneriffe, of drawing upon the outline of a conical mountain the different aspects of its surface from the level of the sea to its highest peak. Thus he could exhibit at a glance all the successive zones of vegetation. Afterward he extended these comparisons to the temperate and arctic zones, and ascertained that, as we proceed further north, the gradation of the vegetation, at the level of the ocean, corresponds to its succession upon mountain slopes,-until, toward the Arctics, it assumes a remarkable resemblance to the plants found near the line of perpetual snows under the Tropics. But this is not all. The intervening expanse from North to South, as far as the equator, and then in reverse order to the Antarctic regions, also exhibits, in proportion to the elevation of the land, a vegetation characterized by intermediate forms.

In the same way he reproduced the general appearance of the inequalities of the earth's surface by drawingideal sections across the regions described. In the first place, through Spain, afterward from La Guayra to Caraccas across the Cumbre, from Cartagena to Santa Fé de Bogotà, and finally through the whole continent of America, from Acapulco to Vera Cruz. And this not by mere approximations, but founding his profiles upon his own barometric and astronomical observations, which he multiplied to such an extent that his works are to this day the chief source of information cencerning the physical geography of the regions visited by him. are thus indebted to him for the whole of that graphic method which has made it possible to delineate, in visible outlines, the true characteristics of physical phenomena; for afterward this method was applied to the representation of the oceanic currents, the direction of the prevalent winds, the tidal waves, the rise and fall of our lakes and rivers, the amount of rain falling upon different parts of the earth's surface, the magnetic phenomena, the lines of equal average temperature, the relative height of our plains, table-lands and mountain chains, their internal structure, and the distribution of plants and animals. Even the characteristic features of the History of Mankind are now tabulated in the same way upon our ethnographical maps, in which the distribution of the races, the highways of navigation and commerce, the difference among men as to language, culture, creeds, nay, even the records of our census, the estimates of the wealth of nations, down to the statistics of agriculture and the averages of virtue and vice, are represented. In short, every branch of mental activity has been vivified by this process, and has undergone an entire transformation under its influence.

His paper upon the isothermal lines was published in the "Memoires de la Société d'Arcueil," a scientific club to which, in the beginning of this century, the most eminent men of the age belonged. Though a mere sketch, the first delineation of the curves uniting aifferent points of the earth's surface which possess the same average annual temperature un-

Not satisfied with this, he under- der varying latitudes, exhibits already 
the characteristic features of these lines, which myriads of observations of a later date have only confirmed. No other series of investigations shows, more plainly than this, to what accurate results an observer may arrive, who understands how to weigh critically the meaning of his facts however few they may be.

The barometrical and astronomical observations upon which his numerous maps are based were computed and reduced to their final form by his friend Oltmanns. They fill two large quarto volumes, and amount to the accurate determination of nearly one thousand localities. They are not taken at random, but embrace points of the highest importance, with reference to the geographical distribution of plants and animals and the range of agricultural products. HuMBOLDT has himself added an introduction to this work in which he gives an account of the instruments used in his observations and the methods pursued by him in his experiments, and discusses the astrenomical refractions in the torrid zone.

Thus the physical geography of our days is based upon Humboldt's investigations. $\mathrm{He}$ is, indeed, the founder of Comparative Geography, that all-embracing science of our globe, unfolded with a master hand by KARL Ritter, and which has now its ablest representative in our own Gurot. His correspondence with Berghads testifies his intense interest in the progress of geographical knowledge. To HumBOLDT this world of ours is indeed not only the abode of man, it is a growth in the history of the Universe, shaped according to laws, by a long process of successive changes, which have resulted in its pre sent configuration with its mutually dependent features. The work upon the Position of Rocks in the two hemisphere tells the history of that growth as it could be told in 1823, and is of course full of gross anachronisms; but at the same time it exhibits the wonderful power of generalization and combina. tion which Humbold possessed,-as, for instance, where he says in few beautiful words, fertile in consequences not yet fully appreciated by the natu. ralists of our day: "When we examine the solid mass of our planet, we perceive that the simple minerals are found in associations which are everywhere the same, and that the rocks do not vary, as organized beings do, according to the differences of latitude or the isothermal lines under which they occur"; thus contrasting in one single phrase the whole organic world with theinorganic in their essential character. In practical geology we owe to him the first recognition of the Jurassic formation. It was he who introduced into our science those happy expressions, "geological horizon" and "independence of geological formations." He also paved the way for Elif de Beadmont's determination of the relative age of mountain chains by his discussion upon the direction of stratified rocks and by the parallels he drew between the age of plutonic and sedimentary formations; nor had it escaped him that distant floræ and faunæ, though of the same age, may be entirely different.

The collection of zoological and anatomical papers, in two quarto volumes, with numerous colored plates, is full of valuable contributions to the Natural History of Animals, from his own pen, as well as that of his collaborators. The most remarkable are his description of the Condor, which must have delighted the French zoologists, who could not fail to compare it with the glowing pages of their own Buffon; his Synopsis of the South American Monkeys, rivalling the works of AUDEBERT and GEOFFroy St.-Hilaire; his account of the Electric Eel and the Catfish thrown out by the burning voleanoes of the Andes, contrasted with the Great Natural History of Fishes by LAcÉPEDE; his paper on the respiration of Crocodiles and the larynx of Birds and Crocodiles, daring upon his own ground the greatest anatomist of the age, the immortal Cuvier. In- 
deed, it must have created a profound sensation in the learned world when a naturalist, all whose previous publications related to physical subjects, suddenly came forward as a master among masters in the treatment of zoological and anatomical questions.

The botanical works appeared under several titles. We have first the "Plantes Équinoxiales" in two folio volumes, with 140 plates, by BoNPLAND; the monograph of the Mélastomacées and that of the Rhéxiées, in two folio volumes, with 120 plates, also by Bonpland; then the Mimosées by Kunth, in one folio volume, with 60 plates; the revision of the Graminées, in one folio volume, with 220 plates, by KUNTH; and finally the "Nova Genera et Species Plantarum" by KunTH, in seven folio volumes, with 700 plates. Altogether thirteen folio volumes, with 1240 plates, most of which are beantifully colored, and remain unsurpassed for fidelity of description and fullness of illustration. Though the descriptive part of these splendid volumes is from the pen of his fellow-traveler BONPLAND, and his younger friend KunTH, it would be a mistake to suppose that Humborot had no share in their preparation. Not only did he assiduously collect specimens during the journey, but it was he who made, on the spot, from the living plant, drawings and analyses of the most remarkable and characteristic trees; the general aspect of which could not be preserved in the specimens gathered for the herbarium. Besides this there are entire chapters concerning the geographical distribution of the most remarkable families of plants, their properties, their uses, etc., entirely written by Huмвold himself. It was he, also, who for the first time divided the areas of the regions he had explored into botanical provinces, according to their natural physical features; thus distinguishing the Flora of New Andalusia and Venezuela from that of the Orinoco basin, that of New Granada, that of
Quito, that of the Peruvian Andes, and those of Mexico and Cuba. It was he, also, who first showed that the whole Vegetable Kingdom contains, after all, but a few distinct types, which characterize the vegetable carpet of the earth's surface, in different part of the world under different latitudes and at different heights. He closes one of these expositions with a few words, which I caunot pass by without quoting. "Such investigations," he says, "afford an intellectual enjoyment and foster a moral strength which fortify us against misfortunes, and which no human power can overcome"

In 1827 , at the urgent solicitation of his brother, Humboldt transferred his residence from Paris to Berlin. With this step there opens a new phase in his life. 'Thus far he had been absolutely independent of public or official position. Conducting his researches as a private individual, if he appeared before the public at all, it was only in reading his papers to learned Academies. Now he began to lecture in the University. In his first course, consisting of sixty-one lectures, he sketched the physical history of the world in its broadest outlines,-it was, in truth, the programme of the Cosmos. Since I shall give an analysis of this work in its fitting place, I will say nothing of the lectures here, except that as a teacher, he combined immense knowledge with simplicity of expression, avoiding all technicalities not absolutely essential to the subject.

In the midst of his lectures there came to him an invitation from the Russian government to visit the Russian provinces of Asia. Nothing could be more gratifying to a scientific man than the terms in which this proposition was made. It was expressly stipulated by the Emperor that he wished the material advantages which might accrue from the expedition to be a secondary consideration. HuмвоLdт was to make scientific research and the advancement of knowledge his first aim, and 
he might turn his steps in whatever direction he chose. Never before had any government organized an expedition with so little regard to purely utilitarian considerations.

This second great journey of HumBOLDT is connected with a hope and disappointment of my own. I was then a student in Munich. That University had opened under the most brilliant auspices. Almost every name on the list of professors was also prominent in some department of science or literature. They were not men who taught from text-books or even read lectures made from extracts of original works. They were themselves original investigators, daily contributing to the sum of human knowledge. Martius, Oken, Dóllinger, Schelling, Fr. von BaAder, W AGler, Zcccarint, Fuchs, Vogel, von Kobel., were our teachers. And they were not only our teachers but our friends. The best spirit prevailed among the professors and students. We were often the companions of their walks, often present at their discussions, and when we met for conversation or to give lectures among ourselves, as we constantly did, our professors were often among our listeners, cheering and stimulating us in all our efforts after independent research.

My room was our meeting-place,bedroom, study, museum, library, lecture-room, fencing room,-all in one. Students and professors used to call it the little Academy. Here Schimper and Braun for the first time discussed the laws of phyllotaxis, that marvelous rhythmical arrangement of the leaves in plants which our great mathematician in Cambridge has found to agree with the periods of the rotation of our planet. Among their listeners were Professors Martius and Zuccarini; and even RoBert Brown, while in Munich, during a journey through Germany, sought the acquaintance of these young botanists. Here for the first time did Michaheli.es lay before us the results of his exploration of the
Adriatic and adjoining regions. Here BorN exhibited his wonderful preparations of the anatomy of the Lamper-Eel. Here RudolpHi made us acquainted with his exploration of the Bavarian Alps and the shores of the Baltic. These my fellow-students in Munich were a bright, promising set,-boys then in age, many of whom did not live to make their names famous in the annals of science. It was in our little Academy that DöLIINGER, the great master in physiology and embryology, showed to us, his students, before he had even given them to the scientific world, his wonderful preparations exhibiting the vessels of the villosities of the alimentary canal; and here he taught us the use of the microscope in embryological investigation. And here also the great German anatomist, Meckes, came to see my collection of fish skeletons, of which he had heard from Döllinger. Such associations, of course, made us acquainted with everything of importance which was going on in the scientific world. The preparations of Huмвогот for his Asiatic journey excited our deepest interest, and I was filled with a passionate desire to accompany the expedition as an assistant.

General $\mathrm{L}_{\mathrm{A}} \mathrm{H}_{\mathrm{ARP}}$, then residing in Lausanne, who had been the preceptor of both the Emperors Alexander and Nicholas of Russia, and who knew Humвolot personally, was a friend of my family, and he wrote to Humbold in my behalf, asking that I might join the expedition as an assistant. But it was not to be. The preparations for the journey were already made, and Ehrenbera and Gustav Rose, then professors at the University of Berlin, were to be his traveling companions. I should not mention the incident here, but that, slight as it was, it marks the beginning of my personal relation with Hсмводыт.

The incidents of Humbordt's Asiatic journey are less known to the public at large than those of his longer 
American ramblings. Short as it was, however,--for he was absent mavend with the far-off range of the only nine months, - he brought to Caucasus. These east-westerly ranges, the undertaking such an amount of collateral knowledge, that its sciəntific results are of the utmost importance, and may be considered as the culmination of his mature research and comprehensiveness of views. Hi; success was insured also by the ample preparations of the Russian government, orders having been given along the whole route to grant him every facility. Descending the Volga to Kasan, and hence crossing to Ikaterinenburg over the Ural Mountains, he passed through Tobolsk on the Irtish, to Barnaul on the Obi, and reached the Altai Mountains on the borders of China, thus penetrating into the heart of Asia. His researches into the physical constitution of what was considered the high table-land of Asia revealed the true features of that vast range of mountains. Touched by his cultivated genius, the most insignificant facts became fruitful, and gave him at once a clew to the real character of the land. The presence of fruit-trees and other plants, belonging to families not known to occur in elevated regions, led him to distrust the existence of an unbroken, high, cold table-land, extending over the whole of Central Asia, and by a diligent comparison of all existing documents on the subject, combined with his own observations, he showed that four great parallel mountain ridges, separated by gradually higher and higher level grounds, extend in an east-westerly direction. First, the Altai, bordering on the plains of Siberia, from the northern slope of which descend all the great rivers flowing into the Arctic Ocean,-as the Irtish with the Obi, the Jenisei and the Lena; then the Thian-Shan, south of the plateau of Soongaria; next, the Kuenlun, south of the plateau of Tartary ; finally, the Himalaya range, separating the plateau of Thibet from the plains of the Ganges. He showed also the connection of the Himalaya Mountains giving form and character to the continent of Asia, are then contrasted with the north-southerly direction of the Ghauts, the Soliman and Bolor range, and the Ural Mountains which divide Europe from Asia. Approaching the great highways, over which the caravans of the East, from Delhi and Lahore, reach the northern marts of Samarcand, Bokhara, and Orenburg, he opens to us the most striking vistas of the early communication between the Aryan civilization and the Western lands lying then in the darkness of savage life. He inquired also into the course of the old Oxus, and the former channels between Lake Aral and the Caspian Sea. The level of that great inland salt lake, about two or three hundred feet lower than the surface of the sea, suggested to him its former communication with the Arctic Ocean, when the Steppes of the Kirghis formed an open gulf and the northern waters poured over those extensive plains. After examining the German settlements about the Caspian Sea, he returned to St. Petersburg by way of Orenburg and Moscow.

The scientific results of this journey are recorded in two separate works, the first of which, under the title of "Asiatic Fragments of Climatology and Geology," is chiefly devoted to an account of the inland volcanoes which he had had an opportunity of studying during this journey. He had now examined the volcanic phenomena upon three continents, and had gained an insight more penetrating and more compreheñsive than was possessed by auy other geologist into their deep connection with all the changes our globe has undergone. Voleanoes were no longer to him mere local manifestations of a limited focus of eruption; he perceived their relation to earthquakes and to all the phenomena coincident with the formation of the inequalities of the earth's surface. 
The contrast between the Siberian winter and the great fertility of the neighborhood of Astracan, where he found the finest vineyards he had ever seen, led him to consider anew the causes of the irregularities of temjerature under corresponding latitudes, and thus to enlarge his knowledge of the isothermal lines, which he had first sketched in his younger years, and the rationale of which he now clearly set forth. In one comprehensive view he showed the con nection between the rotation of the earth, the radiation of its surface, the currents of the ocean, and especially among the latter the Gulf Stream, in their combined influence upon conditions of temperature, producing under identical latitudes such contrasts of climate as exist between Boston, Madrid, Naples, Constantinople, Tif lis on the Caucasus, Hakodadi in Japan, and that part of our own coast in California, where stands the city which bears his own venerated name.

The second work relating to the Asiatic journey appeared under the title of "Central Asia," being an account of his researches into the mountain systems and the climate of that continent. The broadest generalizations relating to the physics of the globe, showing Humbold T's wonderful familiarity with all its external features, are here introduced in a short paper upon the average elevation of the continents above the level of the sea, as compared with the average depths of the ocean. $\mathrm{L}_{\mathrm{A}}$ PLACE, the great geometer, had already considered the subject; but Humbold brought to the discussion an amount of facts which showed conclusively that the purely mathematical consideration of the inquiry, as handled by Laplace, had been premature. Taking separately into consideration the space occupied upon the earth's surface by mountain ridges with that occupied by high table-lands, and the far more extensive tracts of low plains, HumBOLDr showed that the average eleva- tion of the earth, estimated by $\mathrm{I}_{\mathrm{A}}$ PLACE at more than one thousand metres, could in fact be scarcely one third that amount,-a great deal less, indeed, than the average depth of the sea.

In 1830, after his return to Berlin, he was chosen as the fitting messenger from one great nation to another. The Restoration which fol lowed the downfall of NAPOLEON had been overturned by the July revolution, and Humвorot who had lived through the glory of the Republic and the most brilliant days of the Empire was appointed by the King of Prussia to carry an official greeting to Lovis Philippe and the new dynasty. He had indeed the most friendly relations with the ORLEans family, and was, from private as well' as public considerations, a suitable ambassador on this occasion.

Paris had greatly changed since his return from his first great journey. Many of those who had made the glory of the Academy of Sciences, in the beginning of the century, had passed away, and a new generation had come up. Elie de Beaumont, Dufrenor, the younger Brongniart, Adrien de Jussieu, Isidore Geoff roy, Milne Evwards, Audouin, Flourens, Guillemain, Pouillet, Duperrey, Babinet, Decaisne, and others, had risen to distinction, while the older AMpére, the older BrongNIart, Valenciennes, De Blainnille, Arago and Geoffrox St.-Hilame, had come forward as leaders in science. Cuvier, just the age of Humbold himself, was still active and arjent in research. His salon, frequented by statesmen, scholars, and artists, was, at the same time, the gathering-place of all the most original thinkers in Paris; and the pleasure of those delightful meetings was unclouded, for none dreamed how soon they were to end forever,-how soon that bright and vivid mind was to pass away from among us.

In those days a fierce discussion was carried on before the Academy as well as in public lectures. Goethe 
had declared the unity of structure of a foreign court. His official posiin the bony frame of all the Vertebrates, and had laid the foundation of the morphology of plants. These new views had awakened the interests and passions of the whole world of science to a degree hitherto unknown in her peaceful halls. Cuvier, strange to say, had taken ground in opposition to Goethe's views upon the Vertebrate type, while Geofrrox St.Hilatre, a devoted adherent of Goztнe's ideas, had expressed his convictions in words not always courteous toward Cuvier. The latter had retorted with an overwhelming display of special knowledge, under which the brilliant generalizations of St.-Hilatre seemed to be crushed. Cuvier was then giving a course of lectures in the Collége de France on the history of science, into which he wove with passionate animation his objections to the new doctrine. HumBOLDT attended these lectures regularly, and I had frequently the pleasure of sitting by his side and being the recipient of his passing eriticism. While he was impressed by the objections of the master-anatomist, he could not conceal his sympathy for the conception of the great poet, his countryman. Seeing more clearly than Cuvier himself the logic of his investigations, in whispered comments during the lectures, he constantly declared that whatever deficiencies the doctrine of unity might still contain, it must be essentially true, and Cuvier ought to be its expounder instead of its opponent. The great French naturalist did not live to complete these lectures, but the view expressed by his friend was prophetic. Cuvier's own researches, especially those bearing upon the characteristics of the four different plans of structure of the animal kingdom, have helped to prove, in his own despite, though in a modified form, the truth of the doctrine he so bitterly opposed.

The life which Нuмвoudot now led was less exclusively that of a student than it had been during his former Paris life. He was the ambassador tion and his rank in society, as well as his great celebrity, made him everywhere a cherished guest, and Humbold had the gift of making himself ubiquitous. He was as familiar with the gossip of the fashionable and dramatic world as with the higher walks of life and the abstruse researches of science. He had at this time two residences in Paris,-his lodging at the hotel des Princes, where he saw the great world, and his working-room in the Rue de la Harpe, where he received with less formality his scientific friends. It is with the latter place I associate him; for there it was my privilege to visit him frequently. There he gave me leave to come to talk with him about my work and consult him in my difficulties. I am unwilling to speak of myself on this occasion, and yet I do not know how else I can do justice to one of the most beautiful sides of Huмвordt's character. His sympathy for all young students of nature was one of the noblest traits of his long life. It may truly be said that toward the close of his career there was hardly one prominent or aspiring scientific man in the world who was not under some obligation to him. His sympathy touched not only the work of those in whom he was interested, but extended also to their material wants and embarrassments. At this period I was twenty-four; he was sixty-two. I had recently taken my degree as Doctor of Medicine, and was struggling not only for a scientific position, but for the means of existence also. I have said that he gave me permission to come as often as I pleased to his room, opening to me freely the inestimable advantages which intercourse with such a man gave to a young investigator like myself. But he did far more than this. Occupied and surrounded as he was, he sought me out in my own lodging. The first visit he paid me at my narrow quarters in the Quartier Latin, where I occupied a small room in the hotel du Jardin des Plantes, was 
characteristic of the man. After a of study to pursue,-these were the cordial greeting, he walked straight things of which he talked to me on to what was then my library, - a small that delightful evening. I do not book-shelf containing a few classies, mention this trivial incident without the meanest editions bought for a feeling that it may seem too familiar trifle along the quays, some works on for the occasion; nor should I give philosophy and history, chemistry it at all, except that it shows the and physics, his own Views of Na- sweetness and kindliness of Humture, Aristotle's Zoology, Linn eus's BoLDT's nature. It was not enough Systema Naturæ, in several editions, for him to cheer and stimulate the Curvier's Règne Animal, and quite student; he cared also to give a rare a number of manuscript quartos, indulgence to a young man who could copies which, with the assistance of allow himself few luxuries.

my brother, I had made of works I was too poor to buy, though they cost but a few francs a volume. Most conspicuous of all were twelve volumes of the new German Cyclopædia presented to me by the publisher. I shall never forget, after his look of mingled interest and surprise at my little collection, his half-sarcastic question as he pounced upon the great Encyclopædia,_-Was machen Sie denn mit dieser Eselsbrücke?" What are you doing with this ass's bridge? - the somewhat contemptuous name given in Germany to similar compilations. "I have not had time," I said, "to study the original sources of learning, and I need a prompt and easy answer to a thousand questions I have as yet no other means of solving."

It was no doubt apparent to him that I was not over familiar with the good things of this world, for I shortly afterward received an invitation to meet him at six o'clock in the Galerie vitrée of the Palais Royal, whencehe led me into one of those restaurants, the tempting windows of which I had occasionally passed by. When we were seated, he half laughingly, half inquiringly asked me whether I would order the dinner. I declined the invitation, saying that we should fare better if he would take the trouble. And for three hours, which passed like a dream, I had him all to myself. How he examined me, and how much I learned in that short time! How to work, what to do, and what to avoid; how to live; how to distribute my time; what methods the faintest ray of light that may

The last period of his life was spent in Berlin, and while there to the end of his long and laborious career he was engaged with the publication of his Cosmos, and also in editing the great work, on the Kavi language, left by his brother WrLliam, who died in 1835 . Besides these important undertakings, he was unceasingly engaged in fostering magnetic observations and the establishment of magnetic observatories. He likewise felt a lively interest in the proposed interoceanic Canal between the Atlantic and Pacific Oceans, the lines for which he had carefully considered in earlier years. Surrounded by loving and admiring friends, covered with honors and distinctions, these days were rich in peaceful enjoyment.

One of the most prominent features of Нuмвоцит's mind, as philosopher and student of nature, consists in the keenness with which he perceives the most remote relations of the phenomena under consideration, and the felicity with which he combines his facts so as to draw the most comprehensive pictures. This faculty is more particularly exhibited in the Cosmos, the crowning effort of his mature life. With a grasp transcending the most profound generalizations of the philosophers of all ages, he draws at first in broad outlines a sketch of the whole Universe. With an eye sharpened by the most improved instruments of the Observatory, andexalted by the experience of all his predecessors, he penetrates into the remotest recesses of space, to seek for 
furnish any information concerning the expanse of the heavenly vault and the age of the celestial bodies. $\mathrm{He}$ thus makes the rapidity with which light is propagated a measure of the distance which separates the visible parts of the whole system from one another, as well as a means of approximately estimating the duration of their existence. He next considers the various appearances of the celestial bodies, the different kinds of nebulæ, their form and relations to one another and to the so-called fixed stars; describes in graphic and fascinating language the landscape-like loveliness of their combinations in the Milky-Way and the various constellations; discusses the nature of the doublestars, and, gradually ap proaching our own system by a comparison of our sun to other suns, rises, by a sublime effort of the imagination, to a conception of the form of their united systems in space. In the description of our solar system one might have expected an exposition similar to the methods adopted by astronomers; but the object of our great physicist is not to write a synopsis of Astronomy. He plunges without hesitation into the earliest history of the formation of our earth, the better to illustrate the relations to one another of the sun and the planets with their satellites, the comets, and the hosts of meteors of all kinds which come flashing, like luminous showers, through the atmosphere. Our globe is reviewed in its turn. First, its structure, the density of its mass, in the estimation of which the oscillations of the pendulum become a plum met-line with which to fathom the inapproachable deep; then the volcanoes are made to reveal the everlasting conflict between the interior caldrons of melted materials and the consolidation of the ruffled surface; the distribution of heat and light, the climates, as depending upon the in equalities of form and relief, the currents of the ocean, as modifying the temperature, the magnetic phenomena, the aurora borealis, the shooting stars, etc., are discussed in turn. The changes which our globe has undergone in the course of ages are next described: how the lands gradually rose above the level of the sea: how they first formed disconnected archi. pelagos; how mountains grew up in succession, and their relative age ; the form and extent of successively larger continental islands, their plants and animals; -nothing escaped his attention; everything is represented in its true place and relation to the whole. Especially attractive are his delineations of the distribution of plants and animals upon the present surface of the earth, of which an account has already been given.

This mode of treating his subjects, emphatically his own, has led many specialists to underrate Humboldr's familiarity with different branches of science; as if knowledge could only be recorded in pedantic forms and a set phraseology.

But HuMboldt is not only an observer, not only a physicist, a geographer, a geologist of matchless power and erudition, he knows that nature has its attraction for the soul of man; that, however uncultivated, man is impressed by the great phenomena amid which he lives; that he is dependent for his comforts and the progress of civilization upon the world that surrounds him This leads to an appreciative analysis of the enjoyment derived from the contemplation of nature, and to considerations of the highest order respecting the influence which natural highways have had upon the races of men, in their distribution upon the whole surface of the globe.

In speaking of his later days I can not omit some allusion to a painful fact connected with his residence at Berlin. The publication of a private correspondence between VARNHAGEN von Exse and Humboldt has led to many unfriendly criticisms upon the latter. He has been blamed for holding his place at court, while, in private, he criticised and even satirized severely everything connected with 
it. It is not easy to place one's self / remember that his official station in the right point of view with ref- there gave him the means of inerence to these confidential letters. fluencing culture and education in his It must be remembered that Hum- native country in a way which he BOLDT was a Republican at heart. could not otherwise have done, and His most intimate friends, from that in this respect he made the Forster, in his early youth, to noblest use of his position. His symArago, in his mature years, were pathy with the oppressed in every land ardent Republicans. He shared their was profound. We see it in his feelenthusiasm for the establishment of ing for the aborigines in South Amerself-government among men. An anecdote preserved to us by Lieber shows that he did not conceal his sympathies, even before the King who honored him so highly. Lieber, who was present at the conversation, gives the following account of it: "The King of Prussia, Humbold, and NizbuHr were talking of the affairs of the day, and the latter spoke in no flattering terms of the political views and antecedents of Arago, who, it is well-known, was a very advanced Republican of the Gallican School, an uncomprimising French democrat. Frederic William the Third simply abominated Republicanism; yet when Niebuhr had finished, Humbold said with a sweetness which I vividly remembər: "Still this monster is the dearest friend I have in France."

Can we, therefore, be surprised, that in his confidential letters to a sympathizing friend, he should not refrain from expressing his dislike of the petty intrigues and low sentiments which he met among courtiers. I received, myself, a letter from Ним is ) LDT, written in the days when the reactionary movements were at their height in Prussia, in which, in a strain of deep sadness and despondency, he expresses his regret at the turn political affairs had taken in Europe, and his disappointment at the failure of those aspirations for freedom with which he had felt the deepest sympathy in his youth. We may wish that this great man had been wholly consistent, that no shadow had rested upon the loyalty of his character, that he had not accepted the friendship and affection of a King whose court he did not respect and whose weaknesses he keenly felt. But let us ica, in his abhorrence of slavery. I believe that be would have experienced one of the purest and deepest joys of his life had he lived to hear of the abolition of slavery in the United States. His dislike of all subserviency and flattery, whether toward himself or others, was always openly expressed, and was unquestionably genuine.

The philosophical views of HuMBOLDT, his position with reference to the gravest and most important questions concerning man's destiny, and the origin of all things, have been often discussed, and the most opposite opinions have been expressed respecting them by men who seem equally competent to appreciate the meaning of his writings. The modern school of Atheists claims him as their leader; as such we find him represented by Burmeister in his scientific letters. Others bring forward his sympathy with Christian culture as evidence of his adherence to Christianity in his broadest sense. It is difficult to find in Humboldt's own writings any clew to the exact nature of his convictions. He had too great regard for truth, and he knew too well the Aryan origin of the traditions collected by the Jews, to give his countenance to any creed based upon them Indeed, it was one of his aims to free our civilization from the pressure of Jewish tradition; but it is impossible to become familiar with his writings without feeling that, if HumBoLDt was not a believer, he was no scoffer. A reverential spirit for everything great and good breaths through all his pages. Like a true philosopher, he knew that the time had not yet come for a scientific investigation in- 
to the origin of all things. Before he attempted to discuss the direct action of a Creator in bringing about the present condition of the Universe, he knew that the physical laws which govern the material world must be first understood; that it would be a mistake to ascribe to the agency of a Supreme Power occurrences and phenomena which could be deduced from the continued agency of natural causes. Until some limit to the action of these causes has been found, there is no place, in a scientfic discussion, as such, for the consideration of the intervention of a Creator.

In the closing paragraph of the first volume of the Cosmos Humbold distinctly objects to the consideration of the sphere of intelligence in connection with the study of Nature. But the time is fast approaching, and indeed some daring thinkers have actually entered upon the question, -Where is the line between the inevitable action of law and the intervention of a higher power? where is the limit? And here we find the most opposite views propounded. There are those who affirm that, inasmuch as force and matter are found to be a sufficient ground for so many physical phenomena, we are justified in assuming that the whole universe, including organic life, has no further origin. To these, I venture to say, Humbold did not belong. He had too logical a mind to assume that an harmoniously combined whole could be the result of accidental occurrences. In the few instances where, in his works, he uses the name of God, it appears plainly that he believes in a Creator as a lawgiver and primary originator of all things. There are two passages in his writings especially significant in this respect. In the second volume of the Cosmos, when speaking of the impression man receives from the contemplation of the physical world, he calls nature God's majestic realm,_-"Gottes erhabenes Reich." In his allusion to the fear ful catastrophe of Carracas, destroyed by an earthquake in 1812 , the critical inquirer may even infer that HuMBOL๘T believed in a special Provi. dence. For he says with much feeling: "Our friends are no more, the house we lived in is a pile of ruins; the city I have described no longer exists. The day had been very hot, the air was calm, the sky without a cloud. It was Holy Thursday; the people were mostly assembled in the churches. Nothing seemed to foreshadow the threatening misfortune. Suddenly, at four o'clock in the afternoon, the bells which were struck mute that day began to toll. It was the hand of God, and not the hand of man, which rang that funeral dirge." In his own words: "Es war Gottes, nicht Menschenhand, die hier zum Grabgeläite zwang."

One word more before I close. I have appeared before you as the representative of the Boston Natural History Society. It was their proposition to celebrate this memorable anniversary. I feel grateful for their invitation, for the honor they have done me. I feel still more grateful for the generous impulse which has prompted them to connect a HumBOLDT scholarship, as a memorial of this occasion, with the Museum of Comparative Zoology at Cambridge. I trust this token of good-will may only be another expression of that emulation for progress which I earnestly hope may forever be the only rivarly between these kindred institutions and their younger sister in Salem. We have all a great task to perform. It should be our effort, as far as it lies in our power, to raise the standard of culture of our people, as НсмвоцDт has elevated that of the world. May the community at large feel with equal keenness the importance of each step now taken for the expansion, in every direction, of all the means of the highest culture. The physical suffering of humanity, the wants of the poor, the craving of the hungry and naked, appeal to the sympathy of every one who has a human heart. But there are necessities which only the destitute stu- 
dent knows; there is a hunger and thirst which only the highest charity can understand and relieve, and on this solemn occasion let me say that every dollar given for higher education, in whatever special department of knowledge, is likely to have a greater influence upon the future character of our nation than even the thousands and hundreds of thousands and millions which have already been spent and are daily spending to raise the many to material ease and comfort.

In the hope of this coming golden age, let us rejoice together that HumBOLDT's name will be permanertly connected with education and learning in this country, with the prospects and institutions of which he felt so deep and so affectionate a sympathy.

At the Evening Reception which followed the Memorial Address, Professor FreDERIC H. HEDGE, of Harvard University, spoke as follows:

Mr. Chatrman-It is hard gleaning in a field in which Agassiz has been with his sickle. But since you call upon me, I will say that the thing which most impressed me, as I listened to the discourse this afternoon, was the psychological marvel of such a nature as Homboldt's, and the illustration it affords of the capabilities of the human mind. Here was a man whose inappeasable greed of knowledge had appropriated all the science of his time, who knew all that was known in his day of things below and things above. The word "Cosmos," the title he gave to his immortal work, is an apt designation of the mind of the author, - a mind in which the universe mirrored itself in all its vastness and all its minuteness, with its infinitely great and its no less amazing infinitely little. Where shall we look for the parallel and peer of such a mind? To find his match we have to go back two thousand years. We cannot stop at the name of Laplace or of Buffon; these men were great in single provinces of science, but HсмвогDT was great in all. We cannot stop at Newton or Leibnitz, though Newton seems to have gravitated with a more absolute aplomb to the truth of fact, and though Leinnitz pierced with a finer aperou to the heart of things. $\mathrm{We}$ cannot stop at BACON, whose merit is not to have found, nor even to have sought with sincerity, but only to have taught men what and how to seek. We cannot stop till we come to Aristotle. And here we have an even parallel. Between Hмвоцdт and Aristotle there are, it seems to me, some points of striking resemblance. Both of these sages mastered and extended the science of their time,with this difference in favor of the Greek, that he explored the realm of ideas as well as of things; with this difference in favor of the German, that the science of things and their relations - cosmic science - was a thousand-fold more complex and difficult in the nineteenth century of the Christian era than in the fourth of the ante-Christian. Both were fortunate in being partakers of the recent stimuolus given by a great philosophic movement, - that of Socrates in the one case, in the other that of Kant. Both were contemporaries of great world-conquerors and shared the impulse imparted to their time,-the one by Alexander, the other by $\mathrm{N}_{\mathrm{A}}$ POLEON the first.

Dante called Aristotle "il maestro di color' che sanno,"-master among them that know. And what better title can be conferred upon HumBoLDT? Master among them that know, - the master savant

Another thing which fills my soul with profound admiration when I think of HuMBOLDT is the heroism of his life, -a life which exceeded in breadth as well as in length the ordinary limits of mortality. I admire his loyal devotion to the single aim of extending the area of the human mind. I admire the indomitable enterprise which ransacked the globe in seareh of materials with which to build his monumental Cosmos. I admire no less the indefatigable in- 
dustry which methodized and shaped those materials for after ages. A new standard of the possibilities of a single life is given in what he was and what he did. There was no senescence in his experience. He passed away in the midst of tasks which the noon of his life bequeathed to its evening, and which the evening did not seek to escape. And when he died, it seemed as if the civilized world, from the Himalaya to the Andes, sighed in sympathy with the going down of a man who carried a universe in the lobes of his brain, and who counted an ally and a friend wherever nature had a studedent or science a home.

One thing more. The professor has told us of the service which HumBöLDT rendered to humanity by freeing men from the pressure of Jewish tradition. I accept the statement. From all that was puerile and inadequate in Jewish or Jew-Christian theology he was free himself, and helped to make others free. But the central truth of Judaism, the truth of Semitic monotheism, was as true to him as to any before or since. An impression went abroad at the time of his death that HсMвоLDT was an atheist. We all know how loosely, how unthinkingly, that term is applied. That he did not receive the authropomorphism of the conception I can well suppose. But that he rejected the idea of a conscious intelligence at the heart of the world-that intelligence which all his life was spent in tracing-nothing shall convince me, not even an unguarded saying of his own. For I am persuaded that without the belief in such an Intelligence, and a purpose and a method corresponding therewith, he would not have had the heart to prosecute his inquiries. For what use or instruction, or what satisfaction would there be in observing and classifying material phenomena, if those phenomena represented no order and obeyed no law? And when we say "Order," Mr. Chairman, and when we say "Law," we say God. And when we affirm the constancy of that order and the certainty of that law, we bear witness of one at least of the attributes of Deity,-his unchangeable reracity. Those stated processes which make the life of nature and which HumBOLDT so loved to note,- the stars in their course, the ever-recurring phases of earth and sky, precession of equinoxes, succession of seasons, gravitation, magnetism,--these are Nature's comment on the text of the Spirit, "God is true." And when Humboldt applied the methods he had learned in academic Europe and the laws announced by students of nature in other centuries,--applied these to the measurement of mountains on the other side of the globe, knowing them to be as apt and applicable then as in all past time, he unwittingly confessed his belief in a God whose "truth endureth through all generations."

But if, after all, it should prove to be the case-if that were possible which I deny-that the greatest scientist of modern time, in his search after truth, had missed the first and most essential of all truths, - the being of God,- what then? Why then I should say that the man himself is the most convincing proof of the truth he missed. I should feel that the marvel of such a mind, a wonder surpassing any of those it explored, must have had its adequate cause; that the finite intelligence which looked creation through presupposes an infinite Intelligence as its origin and ground. The highest mortal can only be explained as the product of a more than mortal power. 


\section{CONTENTS.}

\section{CHARLES DARWIN.}

I. Introductory Notice. By T. H. Huxley, F.R.S. pages.

II. Life and Character. By G. J. Romates, F.R.S. • • . 2

III. Work in Geology. By ARchibald Geikif, F.R.S. • • • . 7

IV. Work in Botany. By W. T. Thiselton Dyer, F.R.S. • . I:

V. Work in Zoology. By G. J. Romanes, F.R.S. . . . • . If

Vi. Work in Psychology. By the Same. . . . . . . 2 I

ALEXANDER VON HUMBOLDT.

I. Centennial Address, Bý Louis Agassiz. . . . . . 27

iI. Remarks by Prof. Frederic H. Hedge. . . . . . 45 



\title{
PROGRESS AND POVERTY.
}

\section{By HENRY GEORGE.}

\section{6mo. 409 PAGES. PAPER COVER.}

\section{Price, Only 20 Cents.}

\author{
By Mail, 24 Cents.
}

By an arrangement with the publisher of this now celebrated work, I am enabled to supply it retail at the very low price named.

"Progress and Poverty" is universally admitted to be the most original and most forcible work in politico-economic science produced in our time.

The book has been translated into all the languages of continental Europe and it is not too much to say of it, that it is producing a revolution in the domain of sociology and government.

N. B.-As I do not supply the book to the trade, orders should be addressed airect to

\section{J. FIIZG耳EAID,}

\section{Lafayette Place, New Iork.}

** Remittances may be made in One-cent; or Two-cent Postage Stamps.

The price of the $12 \mathrm{mo}$. edition (cloth) is, as before, $\$ 1.00$.

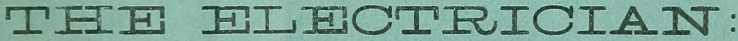

A Monthly Journal of Electrical Science.

Entirely devoted to Electricity in all its branches. All new discoveries and inveniuns in this science are clescribed, and, when necessary, illustrated by woodcuts. Lists of patents, articles from the highest authorities. and the best and latest iaformation connected with the profession of Elertricai Engineering, appear in its jarges. It claims to be the lowest priced Scientific journal in the world.

\section{PUBLISHED BY}

\section{WILEIAITS \& CO., 115 Nassau St., Nev Work.}

Single Copies, \$1.00 a Year; Club Rates, 10 Copies for $\$ 8.00$.

The Electrician and the Humboldt Library, One Year, \$2.00, Postage Paid. Address Peblishri of Either Periodical. 


\section{OATAIOGUE}

OF .THH

\section{Humboldt LibraRy OF Science.}

Price 15 Cents Each Number. To Subscribers, One Year, (12 Numbers,) $\$ 1.50$.

No. I. LIGHT SCIENCE FOR LEISURE HOURS. A series of familiar essuys on astronomical and other natural phenomena.

By Richard A. PROctor, F.R.A.S

No. 2. THE FORMS OF WATER in Clouds and Rivers, Ice and Glaciers. illustrations).

BY JOHN TYNDALL, F.R.S.

No. 3. PHYSICS AND POLITICS. An application of the principles of Nat ural Science to Political Society.

By WAI.TER EAgEHOT, Author of "The English Constitution,"

No. 4. MAN'S PLACE IN NATURE, (with numerous illustrations.)

By Thomas H. Huxley, F.R.S.

No. 5. EDUCATION, Intellectual, Moral and Physical.

By HeRbert SPENCER

No. 6. TOWN GEOLOGY. With Appendix on Coral and Coral Reefs.

By Rev. Chas. Kingsiey.

No. 7. THE CONSERVATION OF ENERGY, (numerous illustrations).

By Balfour Stewart, LT.D.

No. 8. THE STUDY OF LANGUAGES, brought back to its true principles.

BY C. MARCEL.

No. 9. THE DATA OF ETHICS.

BY HERBERT SPENCER.

No. ro. THE THEORY OF SOUND IN ITS RELATION TO MUSIC, ( $n u$ sierous illustrations).

By Prof. Pretro Blaserna.

No. II. THE NATURALIST ON. THE

RIVER AMAZONS. A record

No. I2. of I I years of travel.

By Henry Walter Bates, F.L.S.

No. 13. MIND AND BODY. The Theories of their Relations.

By Alex. BAIN, LL.D.

No. I4. THE WONDERS OF THE HEA VENS, (thinty two illustrations.)

By Camille Flammarion.

No. 15. LONGEVITY. The means of prolonging life after middle age.

By JOHN GARDNER, M.D.

No. I6. THE ORIGIN OF SPECIES.

By Thomas H. Huxley, F.R.S.

No. 17 . PROGRESS; ITS LAW AND CAUSE. With other disquisitions.

By Herbert SPENCER.

No 18. LESSONS IN ELECTRICITY, (sixty illustrations).

By JOHN TYNDALL, F.R.S.

No. 19. FAMILIAR ESSAYS ON SCIENTIFIC SUBJECTS.

By Richard A. Proctor.
No. 20. The ROMANCE of ASTRONOMY.

By R. Kalley Miller, M.A.

No. 2I. THE PHYSICAL BASIS OF LIFE with cther essays.

By Thomas H. HuxLey, F.R.S.

No. 22. SEEING AND THINKING.

By WM. Kingdon CIIFFoRd, F.R.S.

No. 23. SCIENTIFIC SOPHI view of current theories concerning Atoms, Apes and Men.

By SAMURL WAINWRight, D.D.

No. 24. POPULAR SCIENTIFIC LEC. TURES, (illustrated).

By Prof. IH. Helmholtz

Noтв.-The preceding numbers are tto form-like Harpers' Franklin Square Libraxy. The

numbers which follow are 8vo., the size of

Harpers' Monthly.

No. 25. THE ORIGIN OF NATIONS.

By Prof. Geo. Rawlinson, Oxf. Univ.

No. 26. The EVOLUTIONIST AT LARGE

By Grant Allen.

No. 27. THE HISTORY OF LAND HOLDING IN ENGLAND.

By JOSEPH FISHER, F.R.H.S.

No. 28. FASHION IN DEFORMITY, as illustrated in the customs of Barbarous and Civilized Races. (Numer. ous illustrations).

By WM. Henry Flower, F.R.S.

No. 29. FACTS AND FICTIONS UF ZO. OLOGY, (numerous illustrations).

By ANDrew Wilson, Ph, D.

No. 30. $\{$ THE STUDY OF WORDS.

No. 3 r. $\{$ By Richard Chenevix Tresch.

No. 32. HEREDITARY TRAITS, and other essays.

By RICHARD A. PROCTOR.

No. 33. VIGNETTES FROM NATURE.

By Grant Allen.

No. 34. THE PHILOSOPHY OF STY:E.

By Herbert SPENCER.

No. 35. ORIENTAL RELIGIONS.

By JOHN CAIRD, and other authors.

No. 36. LECTURES ON EVOLUIIO : (with numerous illustrations).

By Thomas H. Huxley.

No. 37. SIX LECTURES ON LIGHT, (with numerous illustrations).

By JOHN TYNDAiL, F.R S.

No. 38. I GEOLOGICAL SKETCHES.

No. 39. $\{$ By ARchibal.d Geikie, F. R. S. 

SMITHSONIAN INSTITUTION LIBRARIES

|||||||||||||||||||||||||||||||||||||||||||||||||||||||||||||||||

3 9088008628273 